\title{
Rozmowa z Nadą Prlją
}

\author{
Zofia Waślicka
}

\begin{abstract}
Abstrakt: Nada Prlja to artystka działająca w przestrzeni publicznej, podejmująca kwestie nierówności spoŁecznych i wykluczenia. W ramach 7. Berlińskiego Biennale Sztuki Współczesnej w 2012 roku Prlja zbudowała Peace Wall ('Mur Pokoju') w poprzek jezdni na Friedrichstrasse w Berlinie. Zablokowała w ten sposób ruch między turystyczną, północną częścią tej ulicy z eleganckimi restauracjami i sklepami a jej południową częścią, gdzie znajduje się zamieszkane głównie przez imigrantów osiedle budynków socjalnych. Nada Prlja postanowiła uwidocznić tę symboliczną granicę między bogatą a biedną częścią ulicy i ustawiła tam mur. Jego nazwa nawiązuje do "murów pokoju” (peace walls) oddzielających od siebie protestantów i katolików w Irlandii Północnej.
\end{abstract}

Wyrażenia kluczowe: peace wall, mur pokoju, gentryfikacja, nierówności społeczne, imigranci, polityka miejska, sztuka zaangażowana

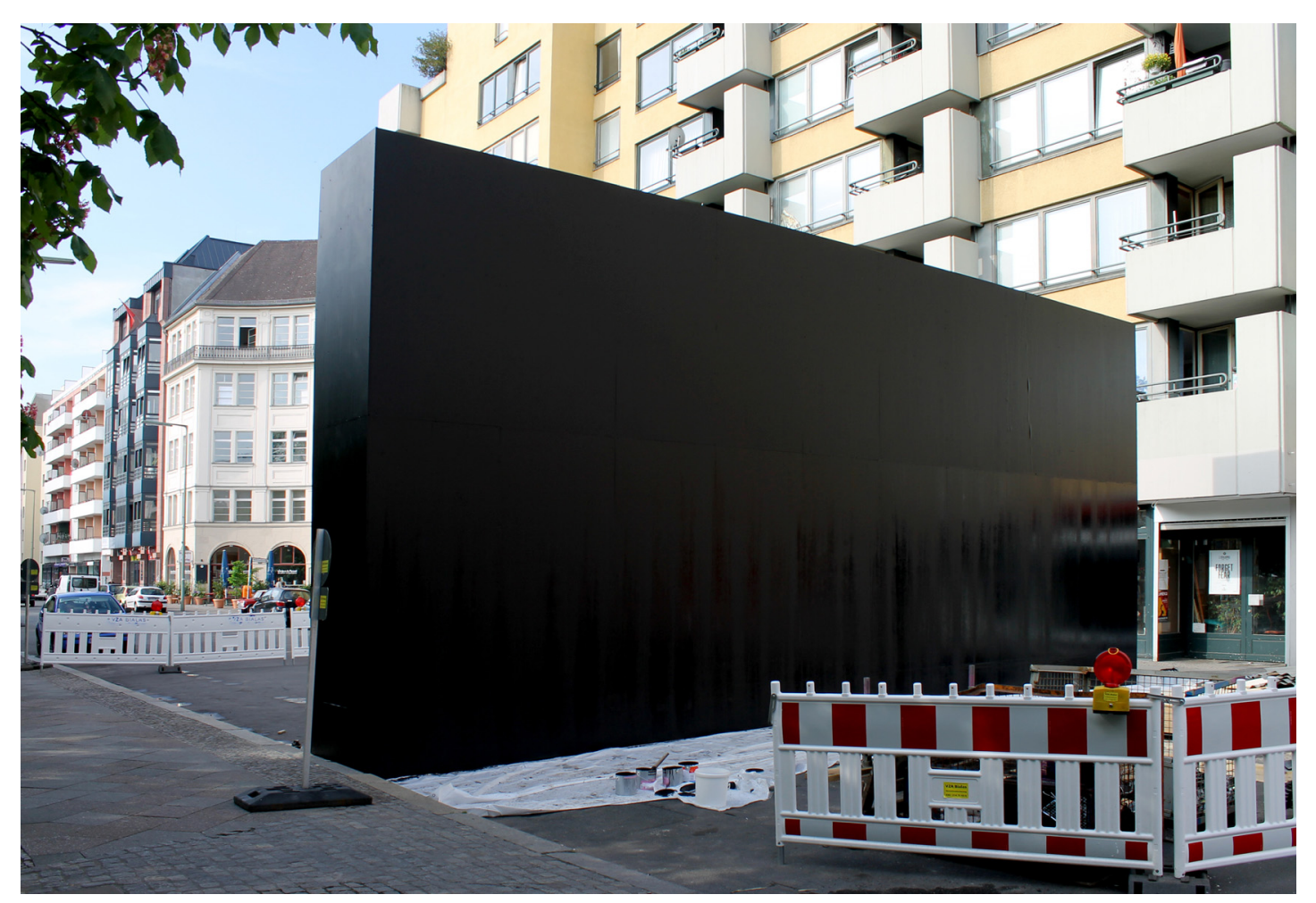

Peace Wall. Fot. Nada Prlja. @ Copyright by Nada Prlja

Pracując przy 7. Berlińskim Biennale Sztuki Współczesnej, poznałam Nadę Prlję. Prlja urodziła się w Sarajewie, od 1998 roku mieszka w Londynie. W swoich poprzednich pracach zajmowała się niesprawiedliwością społeczną, wykluczeniem, nacjonalizmem, skutkami wojny, koncentrując się zawsze na lokalnych problemach miejsc, gdzie pracowała. Nada uważa, że Berlin tylko pozornie jest miastem wolności i beztroski. Jej zdaniem 
mieszkańcy miasta wciąż są nawiedzani przez bolesną i wstydliwą historię, a jednocześnie przyjemne berlińskie życie przyciąga coraz więcej ludzi, którzy wypierają mniej zamożnych berlińczyków. Friedrichstrasse było dla niej miejscem, gdzie doskonale widać wstyd i strach spowodowane zarówno obecną ekonomiczną sytuacją, jak i pamięcią przeszłości. Południowa część tej ulicy to osiedle budynków socjalnych, które powstały na peryferiach Berlina Zachodniego, tuż przy murze. Zamieszkali tam głównie tureccy imigranci. Po zburzeniu muru dzielnica znalazła się w centrum miasta, w atrakcyjnej i turystycznej okolicy, ale sama wciąż zachowała charakter ubogiego przedmieścia. Do dziś 70\% mieszkańców stanowią imigranci, a odsetek osób pobierających zasiłki socjalne jest tam najwyższy w całym Berlinie. To wszystko właśnie się zmienia, jednak nie za sprawą poprawy warunków życia tych ludzi, ale ich kosztem. Turystyczne centrum miasta rozszerza się, eleganckie i hipsterskie bary, sklepy i restauracje pojawiają się coraz dalej na południe ulicy Friedrichstrasse, wypierając tanie, miejscowe lokale. W ich okolicach rosną czynsze i wielu mieszkańców musi się wyprowadzić.

Nada Prlja chciała zwrócić uwagę na sytuację tych ludzi, o których władze miasta nie dbają, a oni sami nie zdobyli się na protest. Chciała też spróbować zatrzymać proces gentryfikacji tej ulicy. Postanowiła wybudować na czas trwania biennale mur w miejscu, gdzie obecnie przebiega symboliczna granica gentryfikacji.

Zablokowanie na ponad dwa miesiące dużej ulicy i jednej z ważnych osi komunikacyjnych miasta wydawało się niemożliwe. Biuro 7. Berlin Biennale wystąpiło jednak oficjalnie z taką prośbą do władz miasta i dopełniło wszystkich wymaganych formalności. Okazało się, że postępując zgodnie z procedurami, można w demokratycznym państwie wybudować mur oddzielający bogatych od biednych.

\section{Zofia Waślicka}

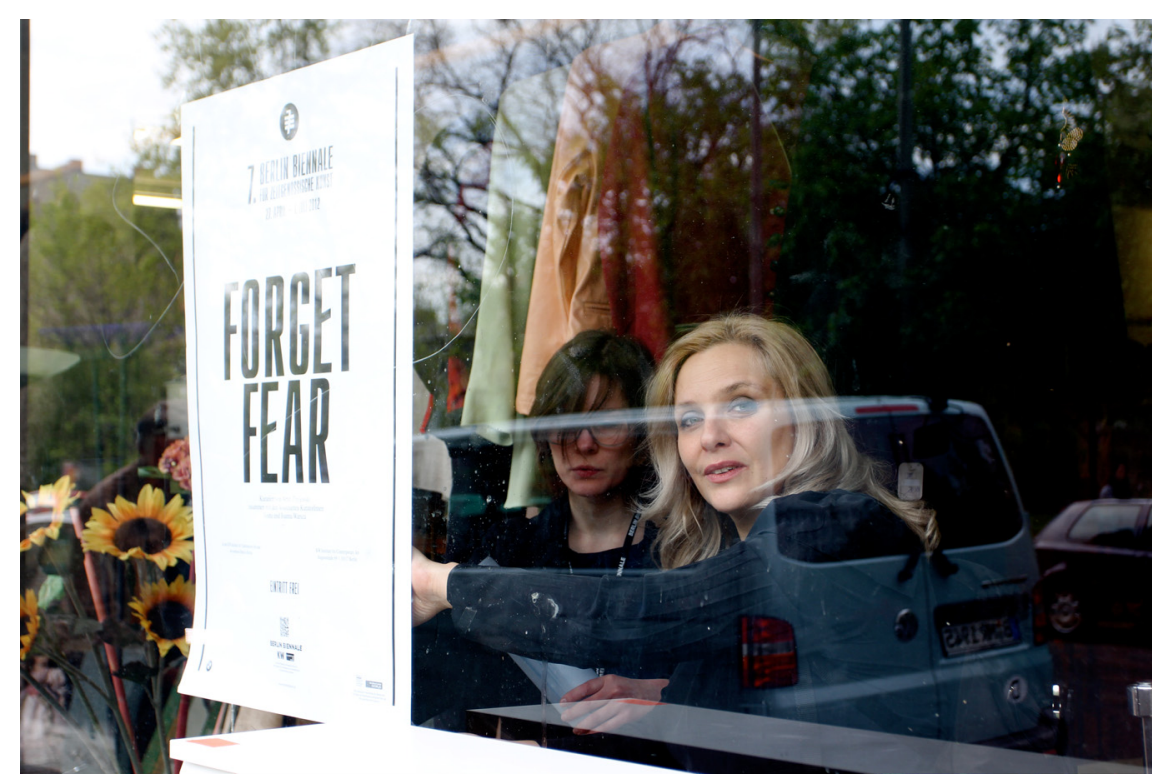

Nada Prlja. Fot. Lidia Rossner. (c) Copyright by Lidia Rossner 
16 czerwca 2012 roku, Berlin

Zofia Waślicka: „Mur Pokoju” został wczoraj rozebrany. Czy możesz opowiedzieć, jak do tego doszło?

Nada Prlja: Jego budowa rozpoczęła się 2 maja i miał stać do końca 7. Berlin Biennale, czyli do 1 lipca 2012 roku. Od samego początku mur wywoływał silne reakcje okolicznych mieszkańców, w sprawę zaangażowały się także partie polityczne. Lokalna wspólnota (mieszkańcy, właściciele restauracji i sklepów) zjednoczyła się przeciwko murowi. Ich protest był na początku dość chaotyczny, jednak pod koniec był już dobrze zorganizowany. Na samym początku to była zwykła agresja - ludzie po prostu krzyczeli na mnie. Po jakimś czasie zorganizowali się w grupę, której liderką była właścicielka sklepu z butami, założyli na Facebooku hejterską grupę i wysyłali do mnie obraźliwe maile. Jeszcze później werbalna agresja zamieniła się w zorganizowany protest. Myślę, że ostateczne doprowadzenie do zburzenia muru bardzo wzmocniło lokalną społeczność. Udało się to, bo sztuka ma w sobie pewną konstytutywną słabość i właśnie dlatego można przeciwko niej walczyć. Gdyby mur powstał z powodów czysto politycznych lub ekonomicznych, mieszkańcy nie potrafiliby się sprzeciwić. Mam nadzieję, że ten skuteczny protest sprawił, że poczuli własną sprawczość i jeśli ktoś stworzy im kolejną „barierę”, będą wiedzieli, jak przeciwko niej walczyć.

ZW: Kiedy twój mur już stał, władze miasta rozpoczęły remont dwóch innych okolicznych ulic. Planując budowę muru, wskazałaś te ulice jako objazd zablokowanego przez ciebie fragmentu Friedrichstrasse. Ich remont, o którym miasto nie informowało wcześniej i który nie był brany pod uwagę przy rozpatrywaniu twojego wniosku, sprawit, że południowa część Friedrichstrasse stała się praktycznie niedostępna dla samochodów. Mieszkańcy protestowali jednak tylko przeciwko twojej blokadzie, także podczas rozmów z burmistrzem dzielnicy.

NP: Mieszkańcy zaakceptowali blokujący ulice remont przekonani, że działania władz miasta są dla nich zawsze dobre, a sztuka jest podejrzana. Mówili: „Artyści nas nie rozumieją, są aroganccy”. Wiele razy pytałam ich: „Dlaczego nie narzekacie, że władze miasta zablokowały objazd? Mogli przecież zaczekać z remontem aż «mur artystki» będzie rozebrany!”. Krytykowanie władz miasta i kierowanie do nich żądań były dla nich nie do pomyślenia. Nasz mur, mimo że był częścią artystycznego projektu, nie różnił się od innych blokad berlińskich ulic. Wypełniliśmy te same formularze, przeszliśmy dokładnie te same procedury, co np. firmy remontujące drogi. Mieliśmy takie samo prawo do blokowania ulicy jak każdy, kto się o to ubiegał i dostał zgodę. Oczywiście mieszkańcy wiedzieli, że artystka, nawet popierana przez instytucję sztuki, jest o wiele słabsza niż władze miasta. W dodatku w przeciwieństwie do zwykle nieosiągalnych polityków pełniących służbę publiczną, ja byłam cały czas obecna przy murze, dostępna dla mieszkańców, wręcz wystawiona na ich ataki. Struktura władzy miasta jest niewidzialna i ludzie nie wiedzą jak ją zaatakować. Rządzący miastem są „nietykalni”. Zatem ludzie oskarżali tylko mnie, 
artystkę, o to, że np. tracą dochody, bo mniej klientów odwiedzało ich sklepy czy bary. Nie brali pod uwagę tego, że to, co robię, ma poparcie instytucji publicznej, która z kolei ma poparcie polityków, prawników... Ludzie zupełnie nie postrzegali mnie jako części systemu. Atakowali tylko najsłabsze ogniwo, czyli artystkę.

ZW: Zorganizowałaś przy murze spotkanie mieszkańców z burmistrzem dzielnicy Kreuzberg. Mieszkańcy południowej części Friedrichstrasse mieli szansę porozmawiać z nim o postępującej degradacji ich dzielnicy, o tym, że kolejne lokalne miejsca bankrutują, ich sąsiedzi są zmuszeni się wyprowadzić, że jeśli nic się nie zmieni, to ich też to czeka. Jednak jedynym tematem rozmów stał się mur, a burmistrza traktowali jak swojego obrońcę przed „szaloną artystką”. A przecież bez jego zgody nie wybudowałabyś muru, który miał zresztą na celu zwrócić uwagę na negatywne skutki gentryfikacji okolicy, będącej rezultatem polityki miasta, czyli właśnie decyzji burmistrza, z którym się spotykali.

NP: To prawda. Ale stworzyliśmy pewną otwierającą sytuację (czego nie byłam wtedy świadoma), ponieważ poprzez atak na mnie [mieszkańcy] atakowali również burmistrza. To przecież on jako funkcjonariusz miasta zezwolił na budowę „Muru Pokoju”. Był zmuszony do wzięcia odpowiedzialności za swoją decyzję i musiał bronić muru, co wiązało się z przyjęciem jego krytycznej wymowy. Podczas tej dyskusji przy murze mówit, że nawet jeśli sztuka jest brutalna w swojej krytyce, powinniśmy tej krytyki wysłuchać.

Byli także inni aktorzy społeczni, którzy wykorzystywali konflikt wokół muru do własnych politycznych celów. Na przykład CDU (Unia Chrześcijańsko-Demokratyczna) zadeklarowała swój sprzeciw wobec muru, żeby zyskać poparcie mieszkańców. Mieliśmy też takich „gentryfikatorów”, jak Florian Schmidt. Schmidt jest szefem biura projektów organizacji „Kreativ Quartier”. Miasto zainwestuje wkrótce dwadzieścia siedem milionów euro w rozwój południowej części Friedrichstrasse i Florian Schmidt oraz jego organizacja chcą za te pieniądze zaprojektować i wybudować centrum kultury na Mehringplatz. Jeśli uda im się przekonać mieszkańców, dostaną dużą część z tych dwudziestu siedmiu milionów. Schmidt jest dla mnie uosobieniem gentryfikacji Berlina i wykorzystywania ludzi do własnych interesów. W tej dzielnicy można by zrobić wiele dobrego za te pieniądze, a on chce je wykorzystać na budowę swojego centrum kultury. Jednocześnie Schmidt krytykował mój projekt i całe berlińskie Biennale, chcąc pokazać, że to właśnie on reprezentuje „dobrą” kulturę.

ZW: Centrum kultury raczej nie rozwiąże problemów mieszkańców.

NP: Schmidt przedstawia się jako osoba szanująca lokalną społeczność, w przeciwieństwie do mnie oczywiście. W rzeczywistości nie dba zupełnie o tych ludzi. Zamierza gentryfikować dzielnicę i wyciągać z tego korzyści dla siebie, ale w ten sposób pogorszy sytuację mieszkańców. Podobnie traktują to miejsce politycy - zamiast zająć się prawdziwymi problemami, tworzą fantastyczne plany na przyszłość. „Mur Pokoju” był odpowiedzią na taką politykę. Nasz mur pokazywał przyszłą perspektywę: prawdziwe podziały za chwilę pojawią się w okolicy jako efekt gentryfikacji. Właściwie już się pojawiają. 
Prawdziwe społeczne i polityczne mury są niewidzialne, ale istnieją bardzo realnie. Nasz mur tylko odzwierciedlat to, co się tam właśnie dzieje - powstaje wiele niewidzialnych murów, które same nie znikną. Wiele razy prosiłam ludzi, żeby spojrzeli w ten sposób na miasto i pomyśleli, jak „Mur Pokoju” może, paradoksalnie, coś im dać. Nasz zaimprowizowany mur dał im okazję do wymyślenia strategii oporu wobec gentryfikacji i innych narzucanych im niechcianych zmian.

ZW: Niedaleko twojego muru są pozostałości Muru Berlińskiego przy Checkpoint Charlie.

NP: Wybudowałam mur niemal dokładnie w tym samym miejscu, gdzie kiedyś stał Mur Berliński. Chciałam poruszyć pamięć ludzi i zobaczyć, jak na to teraz zareagują. Przez wiele lat uważałam Berlin za miejsce wolności, bohemy, przyjemnego, beztroskiego życia. W rzeczywistości jest zupełnie inaczej. Pracując nad „Murem Pokoju”, odkryłam, że jest to miasto pełne bólu, poczucia winy i wstydu. To miasto jest zranione i wciąż krwawi. Ludzie, którzy tu mieszkają, próbują to ukryć i zamazać historię. Myślą: „przeszłość już nie wróci", ale to nieprawda. Ona nadal jest w podświadomości miasta.

ZW: Mur Berliński przemienił tę centralną część miasta w peryferię Zachodniego Berlina.

NP: Budynki przy Mehringplatz zbudowano zaraz po wybudowaniu Muru Berlińskiego. Ich architektura odzwierciedlała idealistyczne, modernistyczne myślenie o nowoczesnym społeczeństwie, ale z powodu usytuowania blisko Muru nikt nie chciał tam zamieszkać. W końcu zasiedlili je imigranci. Dzisiaj stanowią oni 70\% mieszkańców osiedla. Jest to też druga pod względem biedy dzielnica w całym Berlinie. Jednocześnie to miłe i spokojne miejsce. Sąsiedzi się znają, dzieci bawią się razem na ulicach. Ale już niedługo proces gentryfikacji całkowicie zmieni tę okolicę. 27 milionów euro, które miasto chce tu zainwestować, prawdopodobnie wzmocni ten proces, bo władzom bardziej zależy na zwiększeniu atrakcyjności tego miejsca niż na zachowaniu lokalnej wspólnoty. Wielu ludzi będzie musiało się wyprowadzić, ponieważ wzrosną czynsze. Dziwne, że wielu ludzi w ogóle nie zdaje sobie z tego sprawy. Część mieszkańców widzi ten proces i godzi się na to. Młodzi ludzie, z którymi rozmawiałam, mówią: „Berlin musi się rozwijać, trzeba przyciągać turystów”. Akceptują fakt, że turyści są dla miasta ważniejsi niż oni - jego mieszkańcy. Rozmawiając z nimi, starałam się zmienić ich nastawienie, ale to bardzo trudne. Ich rodzice - imigranci czuli się obywatelami drugiej kategorii i ci młodzi czują się tak samo. Młodzi w tej okolicy nie mają w sobie dosyć złości, żeby oprzeć się niesprawiedliwościom, które ich spotykają. To ukryta rzeczywistość Berlina.

ZW: Co media mówiły o „Murze Pokoju”?

NP: Większość dziennikarzy była bardzo krytyczna. Pisali o „szalonej artystce”, „kontrowersyjnym biennale” i o „biednych mieszkańcach”. Koncentrowali się na powierzchownych efektach akcji artystycznej, a nie na problemach lokalnej społeczności, na które chciałam zwrócić uwagę. Media starały się ominąć prawdziwe problemy. Kiedy mówiłam w wywiadach, że południowa część Friedrichstrasse jest upośledzona, dziennikarze odpowiadali, że to nieprawda i że nie można tak mówić, bo to nieładnie wobec ludzi, 
którzy tam mieszkają. Nie starali się zrozumieć i opisać rzeczywistości, przedstawiali jej powierzchowną wizję. Jednak w końcu „Mur Pokoju” zmusił ich do pisania o rzeczywistej sytuacji w tej dzielnicy. Bez tego nie mogliby wyjaśnić genezy projektu. Dziś w aż trzech różnych gazetach znalazłam artykuły, w których wspomniano, że ponad 40\% mieszkańców tej dzielnicy korzysta z zasiłków socjalnych. Taką informację można znaleźć w prasowych komentarzach po ponad miesiącu od wybudowania muru i dzień po jego rozebraniu. 40\% ludzi uzależnionych od zasiłków to najwyższy wskaźnik w Berlinie. Wiele osób tam ani nie pracuje, ani się nie uczy. Są zupełnie bierni. Mur był właśnie po to, żeby ich obudzić, pokazać im, że można sprzeciwić się tej sytuacji i zakwestionować politykę władz miasta. Większość z nich pozostała jednak bierna. Być może to wszystko trwało zbyt krótko.

ZW: Jak to się stało, że miasto zgodziło się na budowę muru?

NP: To dla mnie wciąż niejasne.

ZW: Czy wystarczyło tylko zebrać wszystkie konieczne dokumenty?

NP: Dokładnie tak. Myślę, że to się wiąże z pragnieniem władz Berlina, by pokazać, że nowy, zjednoczony Berlin jest niezwykle wolny, demokratyczny i otwarty. Że to jest „miasto artystów”. Jednak rezultat tego podejścia jest szokujący - z ogromną łatwością można narzucić mieszkańcom coś takiego, jak ten mur, wystarczy tylko dopełnić wszystkich administracyjnych procedur. Władze nie pytają o powód, dla którego coś się robi, nie oceniają celu. Jest coś przerażającego w tym, że w tak liberalnym, demokratycznym systemie właściwie wszystko jest możliwe. Także niedemokratyczne, wykluczające działania.

Oczywiście dla mnie, jako artystki, to dobrze, bo mogę dzięki temu zrobić wiele rzeczy. Mogę stworzyć warunki, w których ludzie czegoś doświadczą, i pracować z ich i moimi głębokimi emocjami. Ludzie byli bardzo poruszeni moim projektem - nie byłam świadoma, że mur w Berlinie wciąż wywołuje tak silne emocje. Starsi ludzie opowiadali mi wspomnienia z czasów podzielonego miasta. „Mur Pokoju” poruszył w nich jakieś pokłady pamięci. Nienawidzili mojego muru, ale chcieli ze mną rozmawiać i o przeszłości, i o dzisiejszych problemach. „Mur Pokoju” okazał się platformą ekspresji dla ich stłumionych emocji.

Jednak większość ludzi milczała. Niektórzy z mieszkańców, zwłaszcza nieposiadający niemieckiego obywatelstwa, uważają się za obywateli drugiej kategorii, bez prawa zabierania głosu. Rozumiem ich. Kiedy przyjechałam do Londynu, byłam postrzegana jako ktoś z kraju objętego wojną, z byłej Jugosławii, i tak też sama o sobie myślałam. Zajęto mi pięć lat, żeby zyskać nową tożsamość - mieszkanki Londynu - i dobrze się z nią poczuć. Dla wielu ludzi mieszkających w południowej części Friedrichstrasse podobny proces jeszcze się nie zakończył. Miałam nadzieję, że ich wspólny protest przeciwko murowi przyspieszy ten proces, że zażądają dla siebie pełnych praw obywateli Berlina. Tak się jednak nie stało. 
Przez długi czas rozmawiałam z mieszkańcami z idealistycznej i nawet nieco naiwnej pozycji. Zastanawiałam się, co możemy razem zrobić z problemami imigrantów i biedą w tej dzielnicy oraz w całym Berlinie, ale takich dyskusji w ogóle nie dało się prowadzić. Mieszkańcy skupiali się wyłącznie na drobnych, tymczasowych problemach, powodowanych przez mur. Narzekali: „Samochód dostawczy potrzebuje o dwadzieścia minut więcej, żeby przywieźć kurczaki do mojego sklepu”; albo: „Kiedy jadę na rowerze, to muszę z niego zsiąść i obejść mur dookoła”. Zajmowały ich tylko drobne problemy. Mówili też ciągle, że w mieście wszystko musi sprawnie działać i artyści nie powinni tego zakłócać. Kiedy pracowałam na terenie byłej Jugosławii, dyskusje wokół moich prac były często bardzo agresywne, ale zawsze dotyczyły spraw ważnych: idei, dążeń, wizji. W Berlinie to się nie zdarzało.

ZW: Jak dużo czasu spędziłaś przy murze?

NP: Na początku chodziłam tam co jakiś czas, potem musiałam wyjechać z Berlina. Kiedy sytuacja stała się poważna, dyżurowałam tam przez dziesięć dni od rana do wieczora. Chodziłam też na spotkania dotyczące planów rozwoju dzielnicy.

ZW: Dlaczego nie udawało się rozmawiać o ważnych sprawach? Może mieszkańców blokował wstyd i strach?

NP: Mieszkańcy nie chcieli być stygmatyzowani. Wielu z nich wciąż nie ma niemieckiego obywatelstwa, nawet jeśli ich rodziny żyją w Berlinie od dwóch czy trzech pokoleń. Przed zjednoczeniem Niemiec mieszkali w tej części miasta tuż przy murze, ponieważ nie mieli wyboru. Nikt inny nie chciał tam mieszkać. Dzisiaj dzielącego miasto muru już nie ma, a ich domy znalazły się w centrum, w coraz bardziej prestiżowym miejscu. Mieszkańcom wydawało się, że ich status społeczny się podnióst, skoro mieszkają teraz w tak atrakcyjnej okolicy. I wtedy zbudowaliśmy im kolejny mur, i zaczęliśmy mówić, że nikt ich tu nie chce i że jeśli nie zaczną działać, to nie zostaną tu zbyt długo. Przypomnieliśmy im, że miasto się z nimi nie liczy.

ZW: Obiecałaś im, że rozbierzesz mur, jeśli przedstawią burmistrzowi postulaty dotyczące polityki miasta wobec ich dzielnicy. Chciałaś stworzyć z mieszkańcami alternatywny scenariusz przyszłości. Czy mieszkańcy faktycznie przygotowali jakieś postulaty?

NP: Nie mieli żadnych postulatów, chcieli tylko zburzyć symbol ich wstydu, czyli mur. Gdy proponowałam im wsparcie w „buncie” przeciwko władzom miasta, miałam świadomość, że jeśli zażądają przestrzegania ich praw, to wspierając ich, wystąpię przeciw burmistrzowi. A to on pomógł mi zrealizować projekt. I później go bronił. Byłaby to dla mnie bardzo niewygodna sytuacja, jednak tego właśnie chciałam, wiedząc, że gdyby mieszkańcy przedstawili żądania i gdybym się zaangażowała w ich walkę, działałabym już nie jako artystka, musiałabym się $w$ to $w$ pełni zaangażować.

ZW: Uważasz, że mieszkańcy mogli użyć muru w swojej politycznej walce? 
NP: Tak. Mieli dzięki niemu łatwy dostęp do mediów, ponieważ przychodziło dużo dziennikarzy z prasy i telewizji. Mogli medialnie wykorzystać np. rozebranie muru, tłumacząc, dlaczego do niego doprowadzili. Mogli nie pozwolić na rozebranie muru, dopóki miasto nie spełni ich żądań. Wiele osób przychodziło do mnie i mówiło, że są szczęśliwi, że mówię o ich problemach. Myślę, że zapoczątkowaliśmy długotrwały proces. Sztuka, i w ogóle kultura, ma taką właściwość, że może się poruszać między sferami polityczną i społeczną, ale nie jest z nimi tożsama. Gdybyśmy byli partią polityczną albo organizacją pozarządową, to mur i wszystko, co on spowodował, nie mogłoby się wydarzyć. Artystę również wiele ogranicza, ale te ograniczenia nie są aż tak sztywne. Działania artystyczne mogą wpływać na sposób myślenia ludzi, którzy w nich uczestniczyli albo byli ich świadkami. Nawet jeśli mieszkańcy Kreuzberga znienawidzili mur, to nauczyli się dzięki niemu czegoś o ukrytych politycznych procesach, przeszli trening skutecznego działania.

ZW: No tak, w końcu wynegocjowali rozebranie muru. Powiedz, co wyróżnia pozycję artysty.

NP: Podczas biennale patrzyłam na ruch Occupy, który przyjmował pozycję „dobrych ludzi" nienawidzących przemocy. Taka pozycja nie zawsze jest efektywna. W sztuce możemy sobie pozwolić na to, żeby powiedzieć otwarcie: „Wcale nie jestem taka dobra. Mogę zrobić coś złego". Sztuka może być autodestrukcyjna, jeśli wymaga tego osiągnięcie pewnego celu. Ruch Occupy nie może być autodestrukcyjny, oni muszą utrzymywać swoją pozycję „dobrych”. Artysta odpowiada na wewnętrzny impuls, który każe mu zaryzykować wszystko, jeśli może to spowodować istotny skutek. Np. sformułowanie przez mieszkańców żądań wobec burmistrza byłoby taką ryzykowną grą, w którą weszłabym całkowicie. Sztuki nigdy nie rozumiałam jako bezpiecznego miejsca.

ZW: Jednak instytucja sztuki nie jest zdolna zaryzykować „wszystkiego” i to ogranicza wolność artysty. Co to jeszcze znaczy, że sztuka może być autodestrukcyjna?

NP: Jeśli to jest potrzebne, możesz np. zburzyć mur - zniszczyć własną pracę, wystąpić przeciw sobie. Sztuka to z definicji łamanie zasad, a więc potencjalne dążenie do destrukcji. „Mur Pokoju” miał taki pozytywnie destrukcyjny potencjał - destruował iluzje ludzi, którzy myśleli, że dzięki temu, że ich dzielnica staje się coraz bardziej prestiżowa, polepszy się ich pozycja społeczna. Tymczasem nie rozumieli, że zostaną z niej po prostu wyrzuceni.

ZW: Zbudowałaś rodzaj przymierza z mieszkańcami - wspólnie doświadczyliście demokratycznego aktu respektowania „woli ludu”. Ugięłaś się przed ich żądaniami i mur rozebrano. Jednak twoja strategia nie jest typowa dla praktyki artystycznej - zwykle obiekty stworzone przez artystów stają się nietykalnymi fetyszami, histerycznie chronionymi przez autorów i galerie.

NP: Moja strategia to zaangażowanie, a nie produkcja fetyszy. Zajmuję się bardzo lokalnymi problemami. Artysta powinien znać kontekst, w którym pracuje. Może rozpocząć jakiś społeczny proces, wywrzeć wpływ na lokalnych mieszkańców, a potem musi odejść 
albo włączyć się w działanie na równych prawach z innymi. Artysta nie ma dziś narzędzi, którymi mógłby zrobić więcej - może tylko zostawić ślad w świadomości ludzi, z którymi pracuje, i liczyć, że oni coś zrobią.

Zawsze pracuję z ludźmi w sposób procesualny. Każdy taki proces jest inny. Nie opowiadam o moim celu działania, skuteczna komunikacja odbywa się także bez słów. Właśnie sztuka potrafi mówić, nie używając słów. Sposób, w jaki przebiega ta pozawerbalna komunikacja, zależy od problemu, nad którym pracujemy. Tym, co chcę osiągnąć, jest lepszy świat. Nie taki hipisowski, kiczowaty świat, ale świat ludzi świadomych wydarzeń i procesów dziejących się w przeszłości, teraz i w nadchodzącej przyszłości - ich wzajemnych relacji i wpływu na indywidualne i zbiorowe życie. Chciałabym sprawić, żeby ludzie przestali żyć jak bohema i myśleć, że wszystko jest pięknie i idealnie. Wielu berlińczyków chciałoby tak myśleć i zamyka oczy na rzeczywistość.

ZW: Głównym elementem twojej strategii w przypadku „Muru Pokoju” było zrobienie czegoś „złego”. Wybudowałaś mur, który ludziom przeszkadzał, przywoływał złe wspomnienia i budził strach przed przyszłością. Sprowokowałaś dużo złości, która skoncentrowała się na tobie, i zaczęłaś z tą złością ludzi pracować.

NP: Wielu artystów przyszłoby do lokalnej społeczności, porozmawiałoby z ludźmi, byliby bardzo mili, a wszyscy i tak by ich nienawidzili, ponieważ czuliby się wykorzystywani przez tych artystów. Budując mur, nie chciałam być miła i szlachetna. Wiedziałam, że ludzie będą mnie nienawidzić, ale to był jedyny sposób, żeby pokazać niewidzialną grę sił i podział między mieszkańcami Friedrichstrasse na lepszych i gorszych. Doświadczenie nauczyło mnie, że ludzie reagują tylko wtedy, kiedy są bezpośrednio skonfrontowani z problemem.

ZW: Jak się czułaś mając władzę? Miałaś od miasta wszystkie potrzebne pozwolenia, żeby zablokować ulicę na cały okres trwania 7. Berlin Biennale. Byłaś jedyną osobą, która faktycznie mogła zdecydować o wcześniejszym rozebraniu muru.

NP: Byłam mocno atakowana. Okoliczni sprzedawcy twierdzili, że z powodu muru drastycznie spadły ich zyski, ale nie wiem, czy to prawda. W każdym razie postawili się w pozycji ofiar i walczyli o swoje sprawy. To było dobre. Sztuka może dać ludziom siłę, ale nigdy nie wiadomo, czy to się uda.

ZW: Czy sądzisz, że po doświadczeniu, jakim była obecność muru przegradzającego Friedrichstrasse, jej mieszkańcy zostali wzmocnieni, czy skutkiem pozostanie ich wstyd?

NP: Jest za wcześnie, żeby to ocenić. Przez niemal dwa miesiące byli w szoku. Najpierw był to szok wywołany pojawieniem się muru, potem świadomością, że mur będzie stał tak długo. Potem była ich walka i w końcu consensus w sprawie rozebrania muru. W tej chwili trudno przewidzieć, jaki będzie efekt tego działania w dłuższym czasie. 
luty 2013 roku

ZW: Od naszej rozmowy minęło osiem miesięcy. Jak dzisiaj patrzysz na historię „Muru Pokoju"?

NP: Nie wiem, co działo się z mieszkańcami południowej Friedrichstrasse po tym, jak wyjechałam. Byłam wyczerpana walką z ambicjami różnych ludzi zaangażowanych w ten proces, czułam, że niewiele więcej można tam zrobić. Wiem, że udało mi się nadwątlić pewien spolegliwy sposób myślenia tych ludzi i uważam to za satysfakcjonujące osiągnięcie.

Wracając w to miejsce mogłabym się tylko przekonać, czy dzielnica zmienia się w sposób, który przewidzieliśmy. I pewnie tak jest, a ja nie chcę karmić się satysfakcją, że nasze przewidywania się sprawdzają.

Cały ten proces nauczył mnie, że zarówno w ludzkich relacjach, jak i działaniach artystycznych jest bardzo mało uczciwości. Straciłam dawną bezgraniczną wiarę w sztukę i ludzi, dotknęłam realnego.

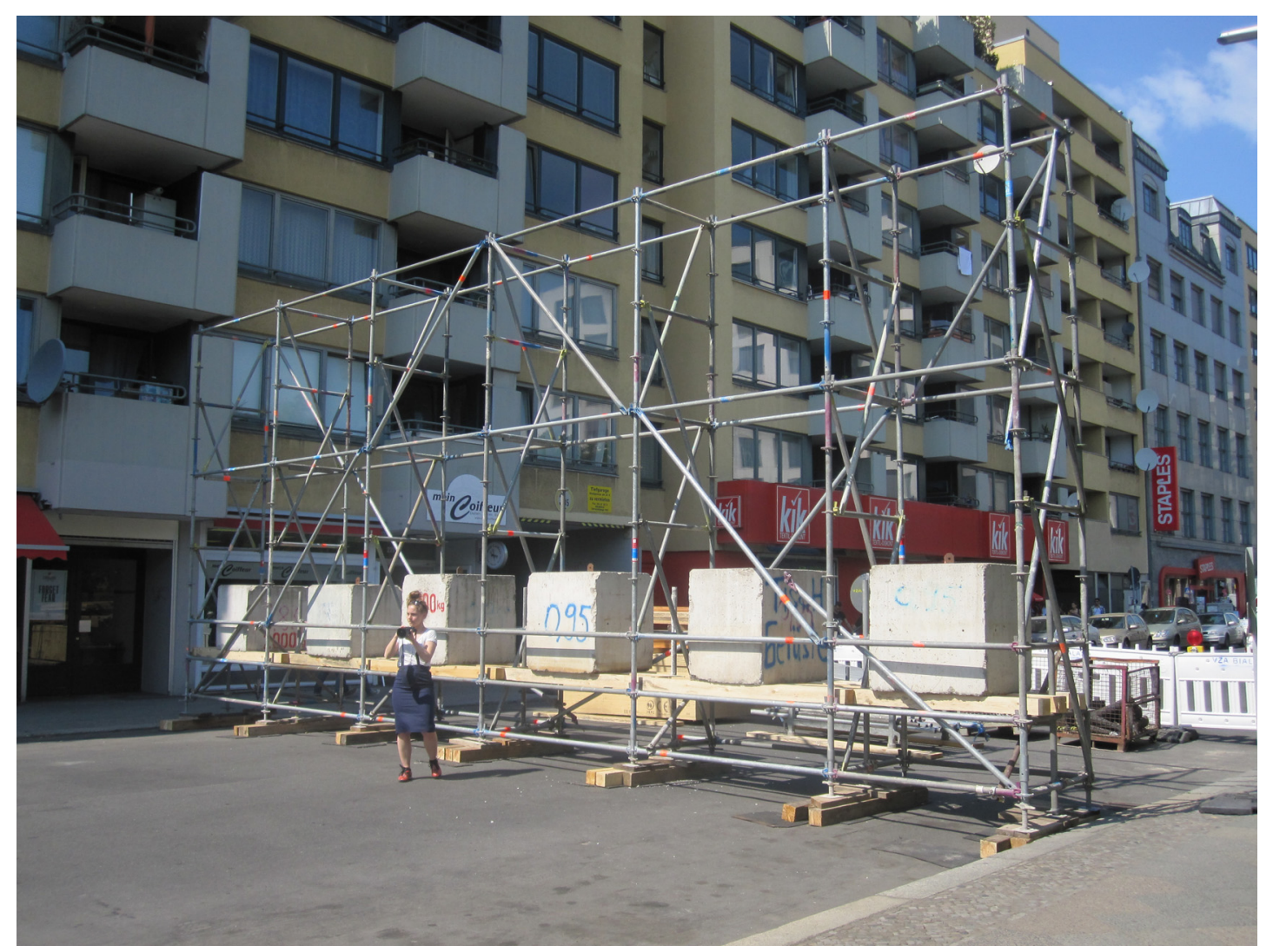

Budowa muru. Fot. Artur Żmijewski. 


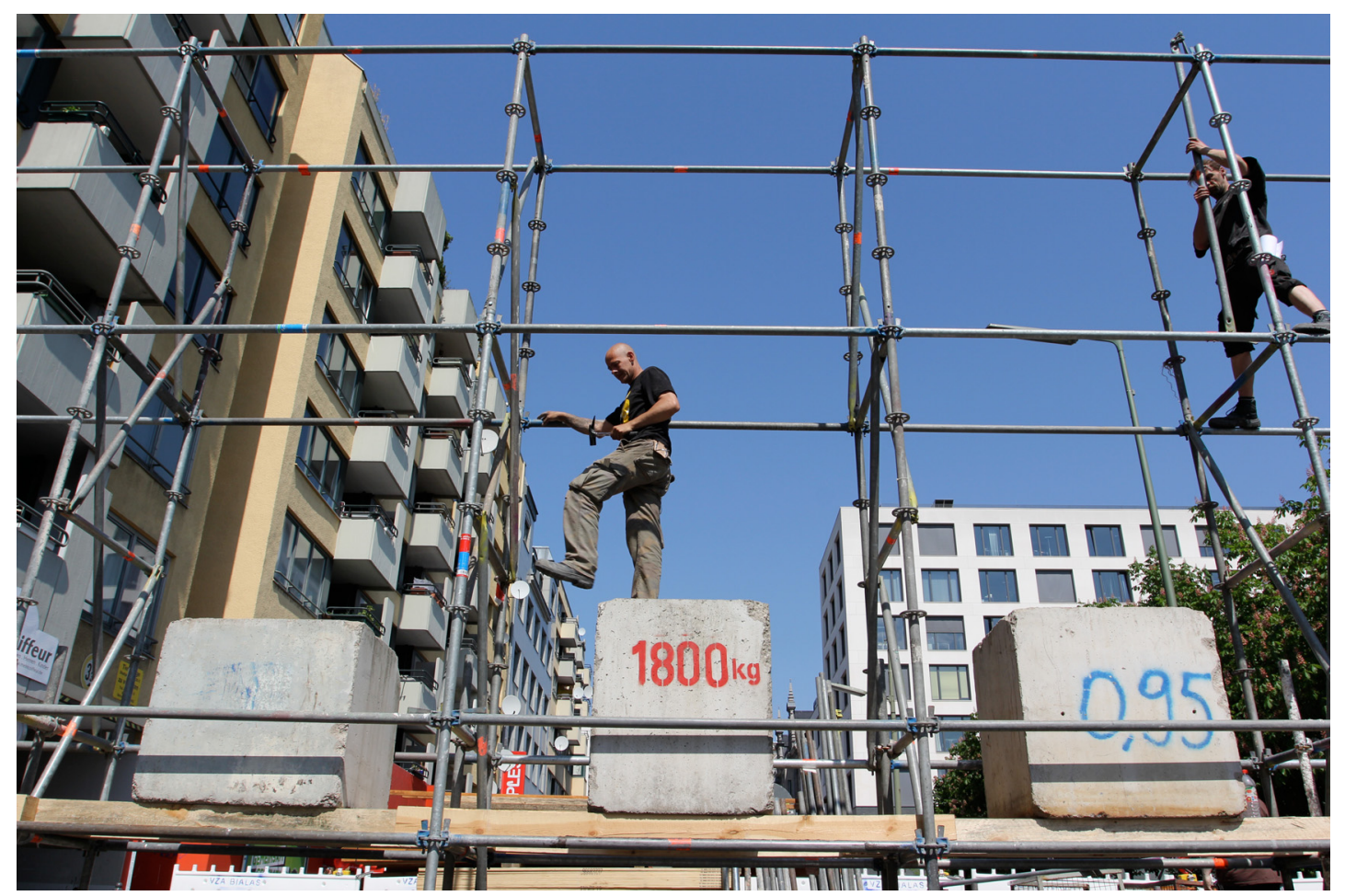

Budowa muru. Fot. Lidia Rossner. (c) Copyright by Lidia Rossner
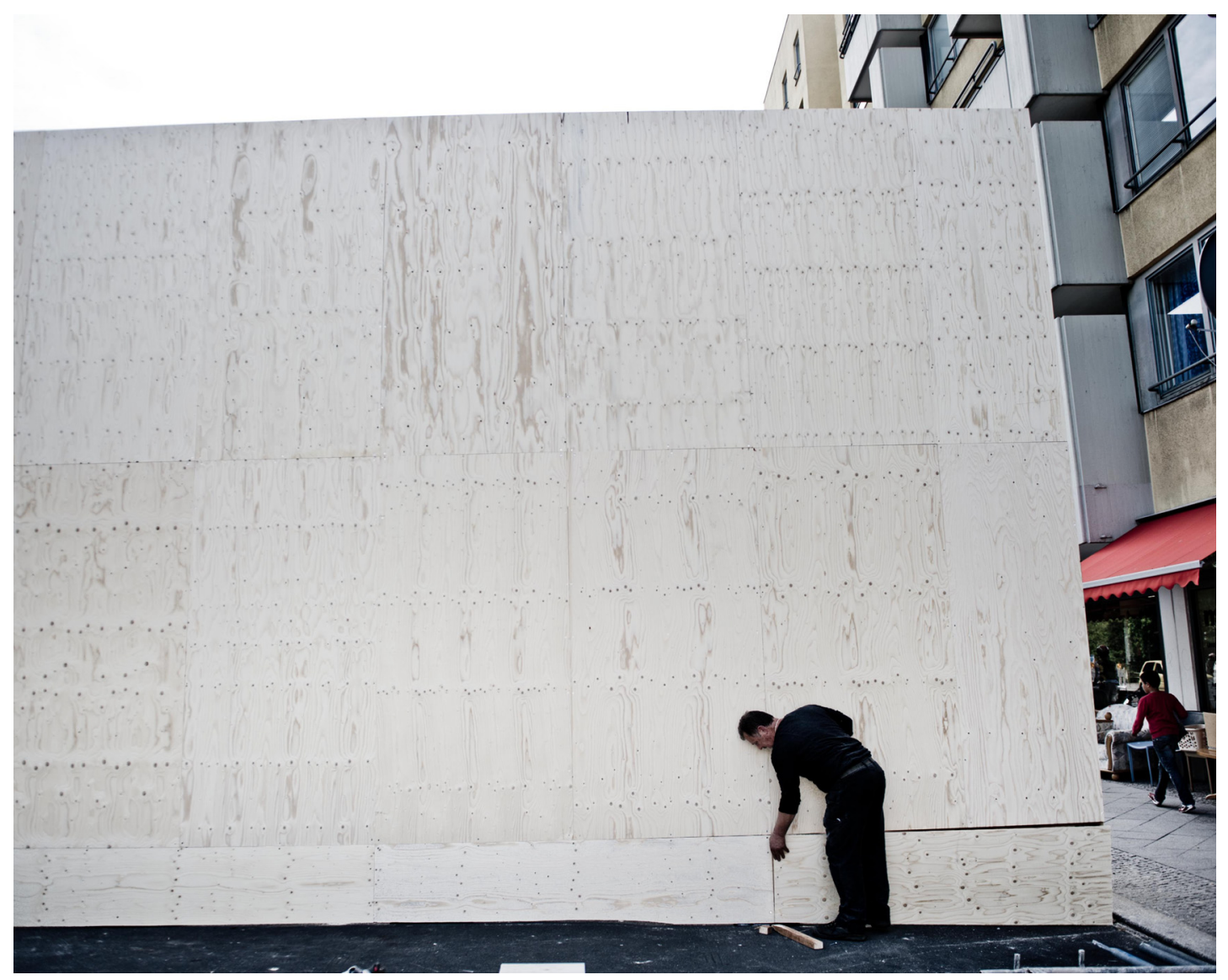

Budowa muru. Fot. Marcin Kaliński. (c) Copyright by Marcin Kaliński 


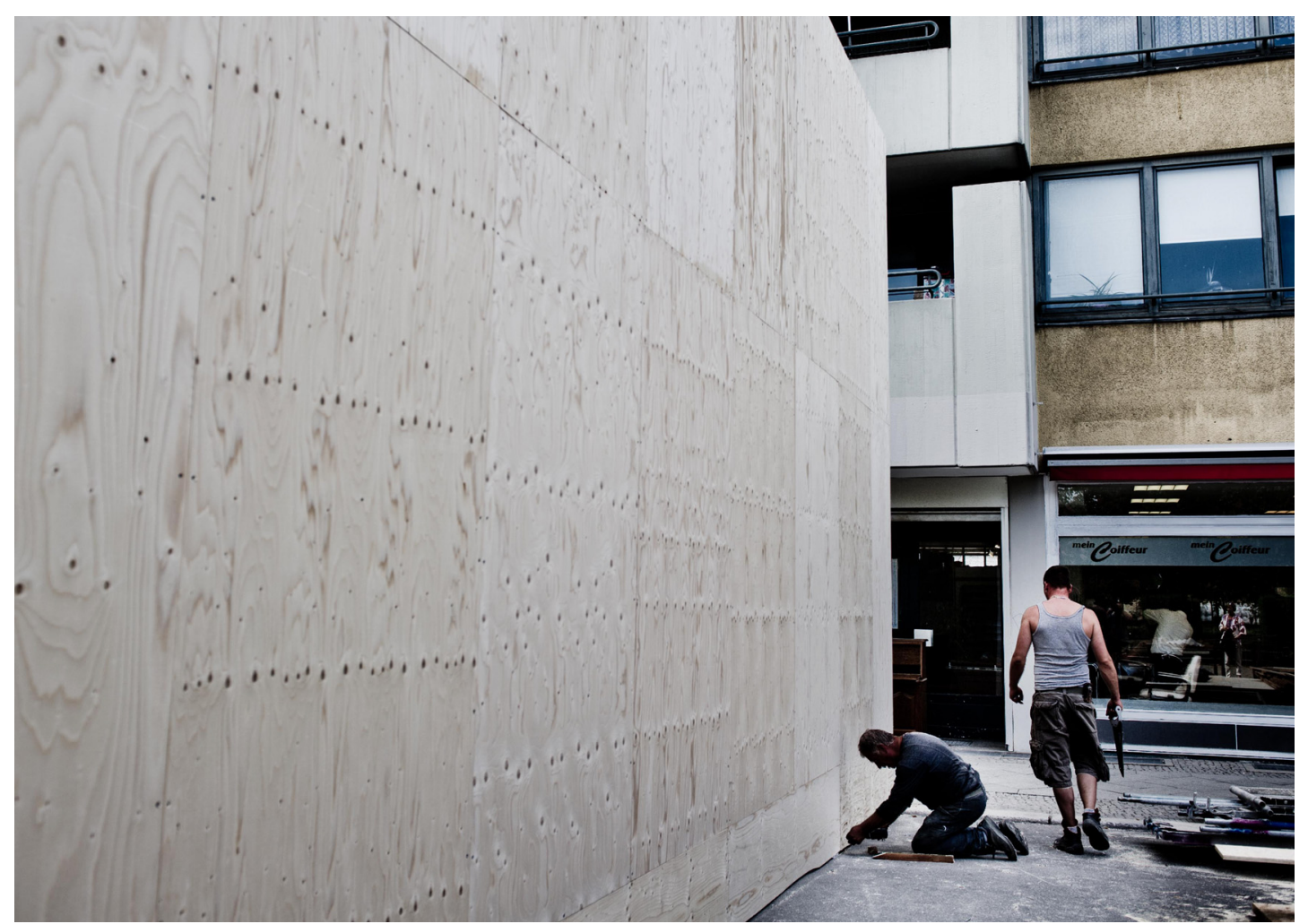

Budowa muru. Fot. Marcin Kaliński. (C Copyright by Marcin Kaliński

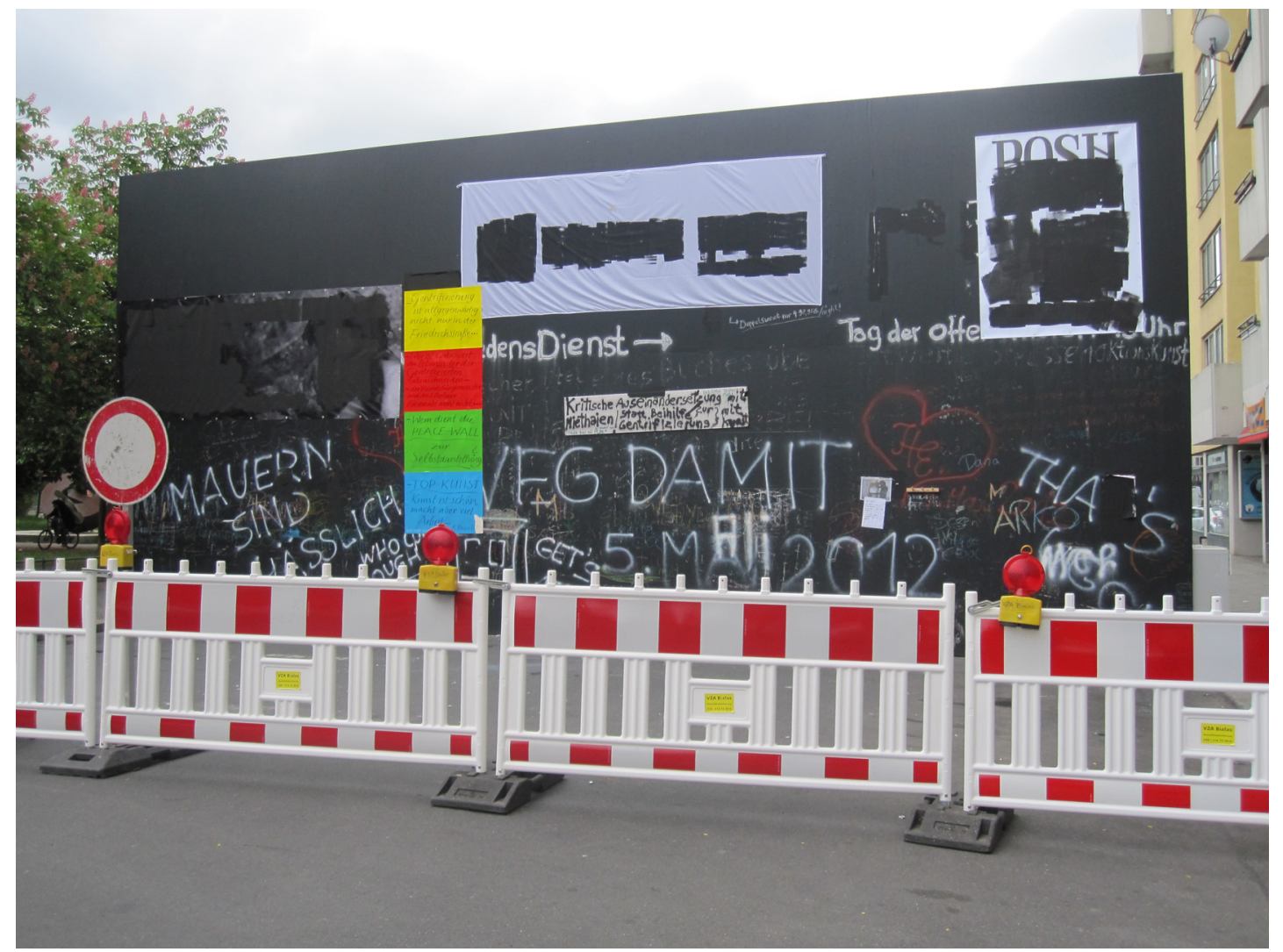

Peace Wall. Fot. Artur Żmijewski. 


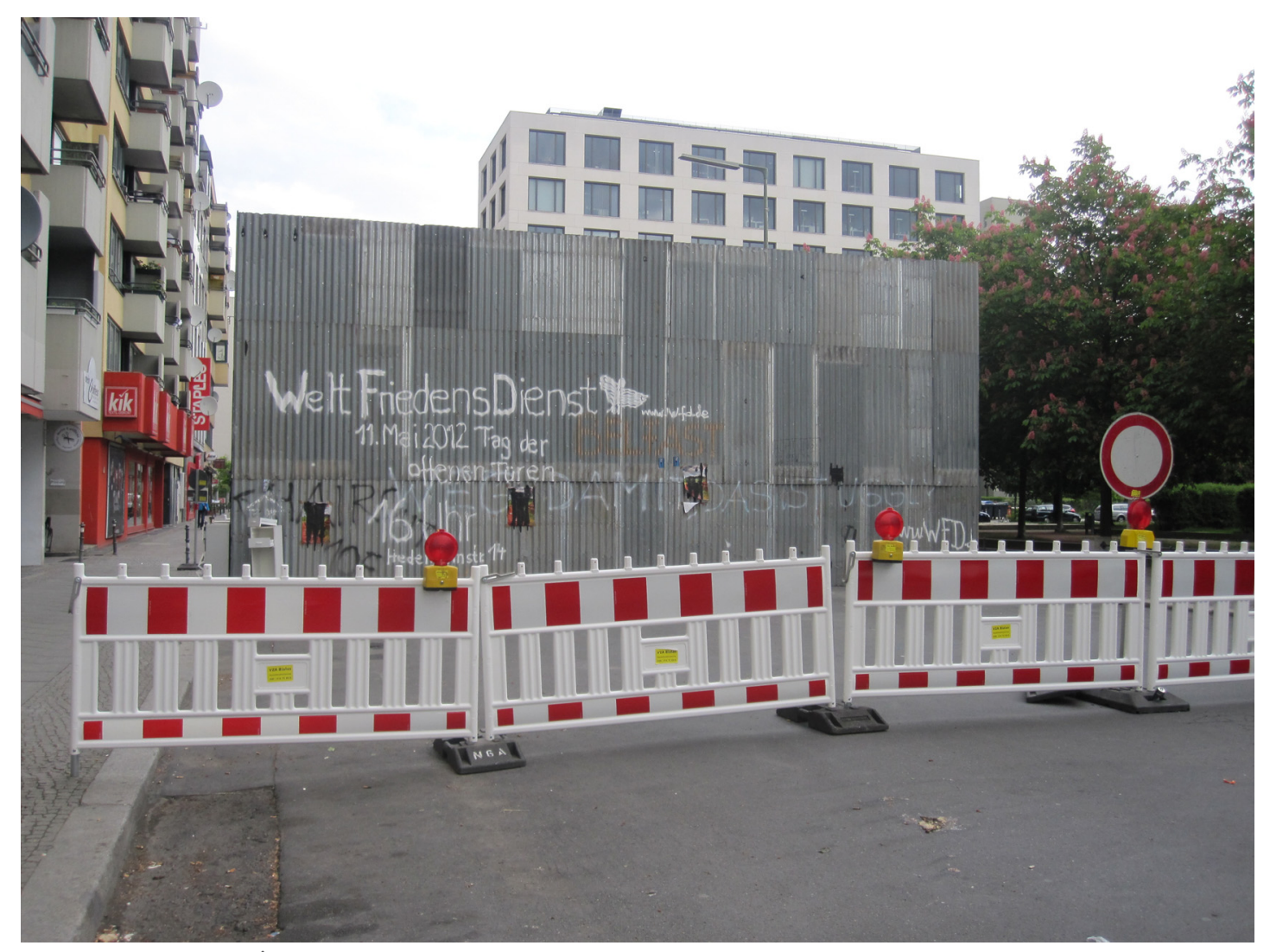

Peace Wall. Fot. Artur Żmijewski.

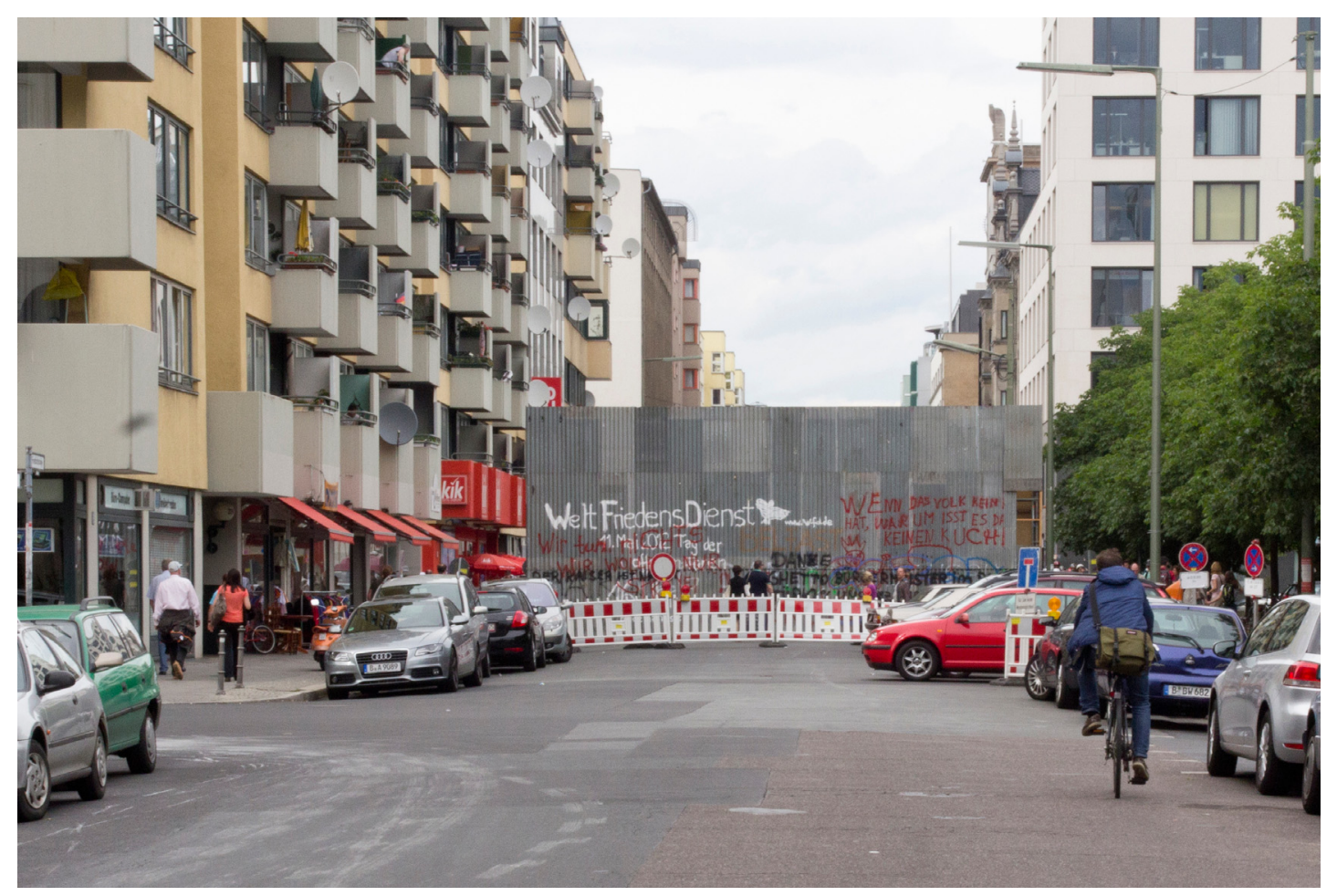

Peace Wall. Fot. Marta Górnicka. 


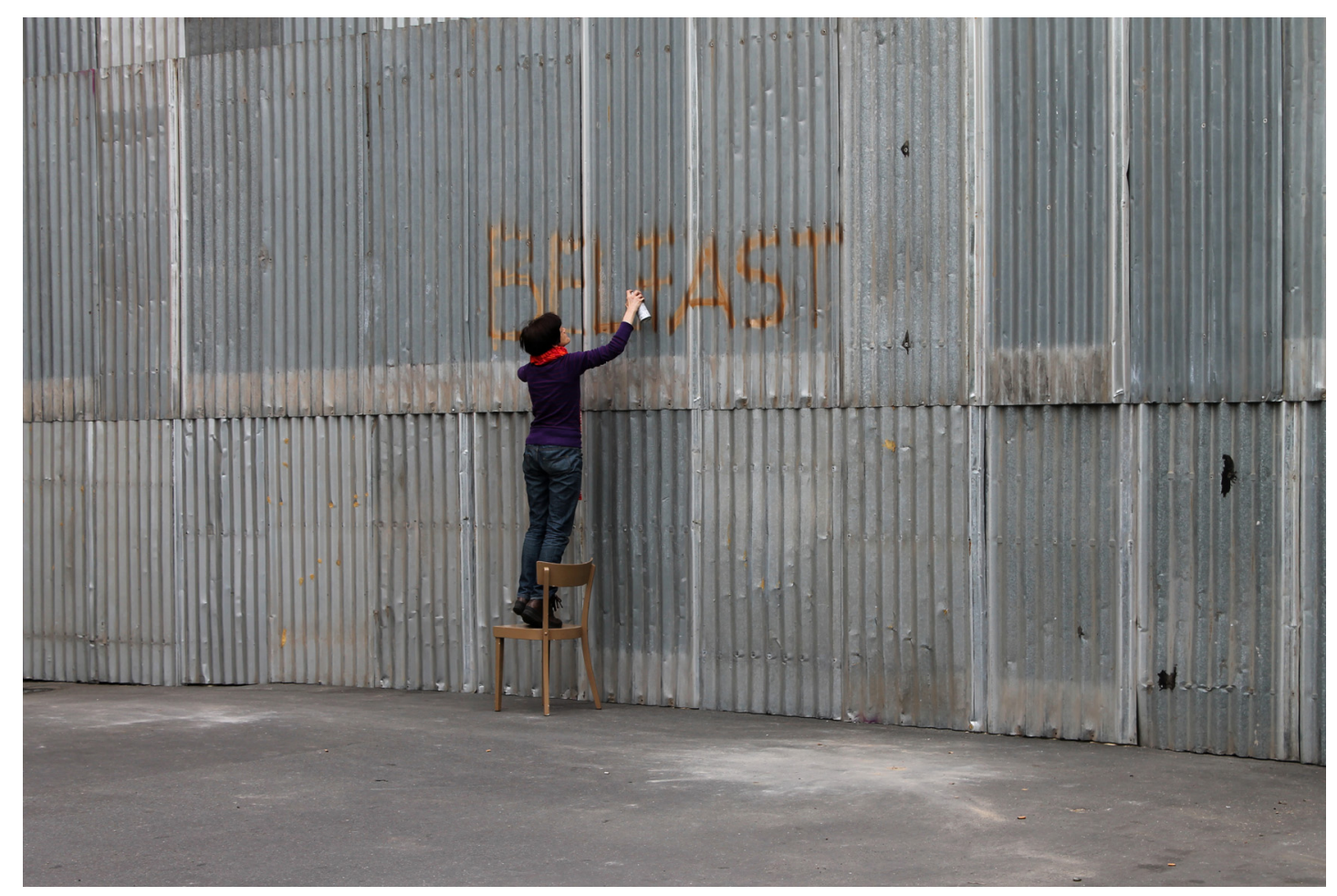

Peace Wall. Fot. Nada Prlja. @ Copyright by Nada Prlja

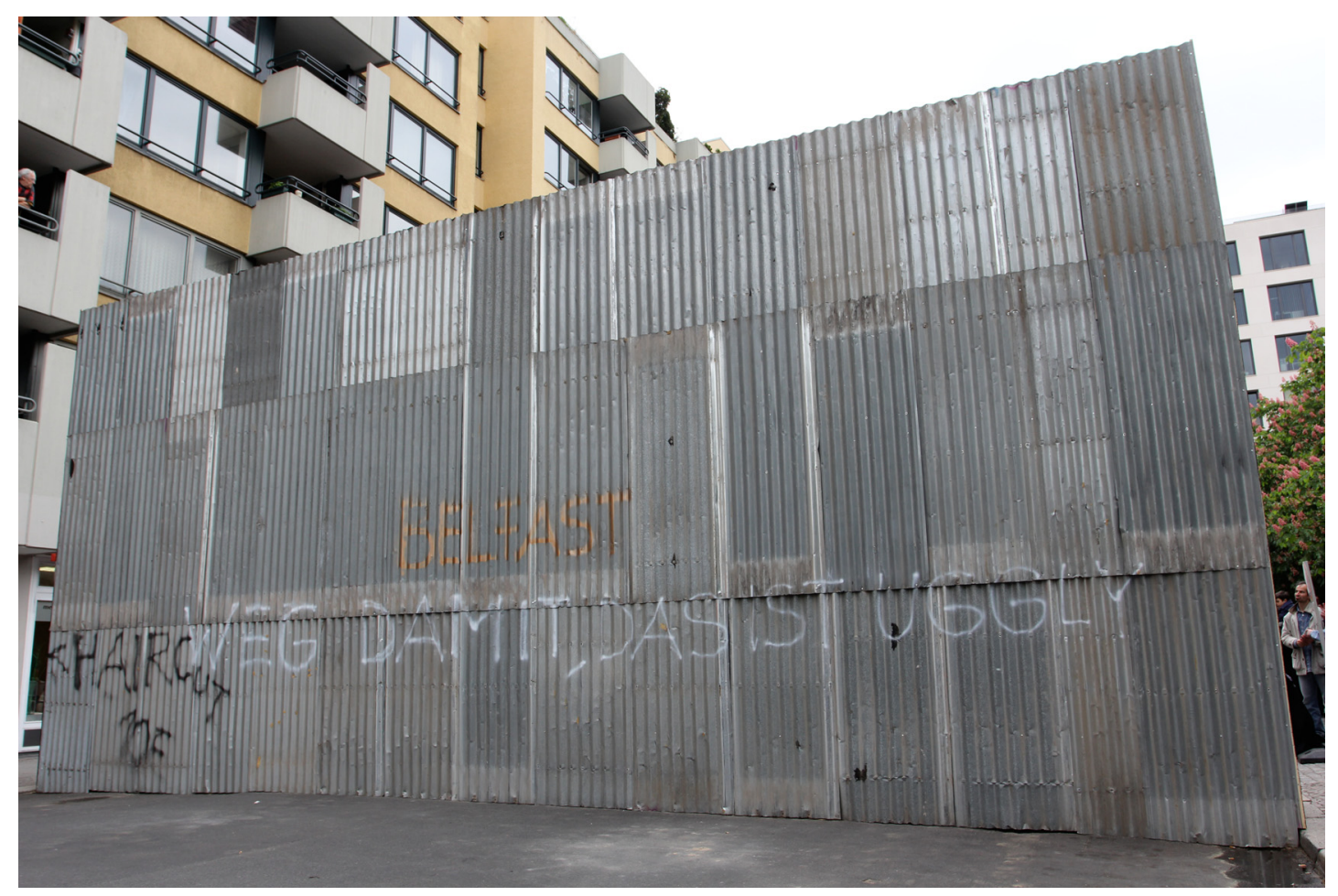

Peace Wall. Fot. Lidia Rossner. (c) Copyright by Lidia Rossner 


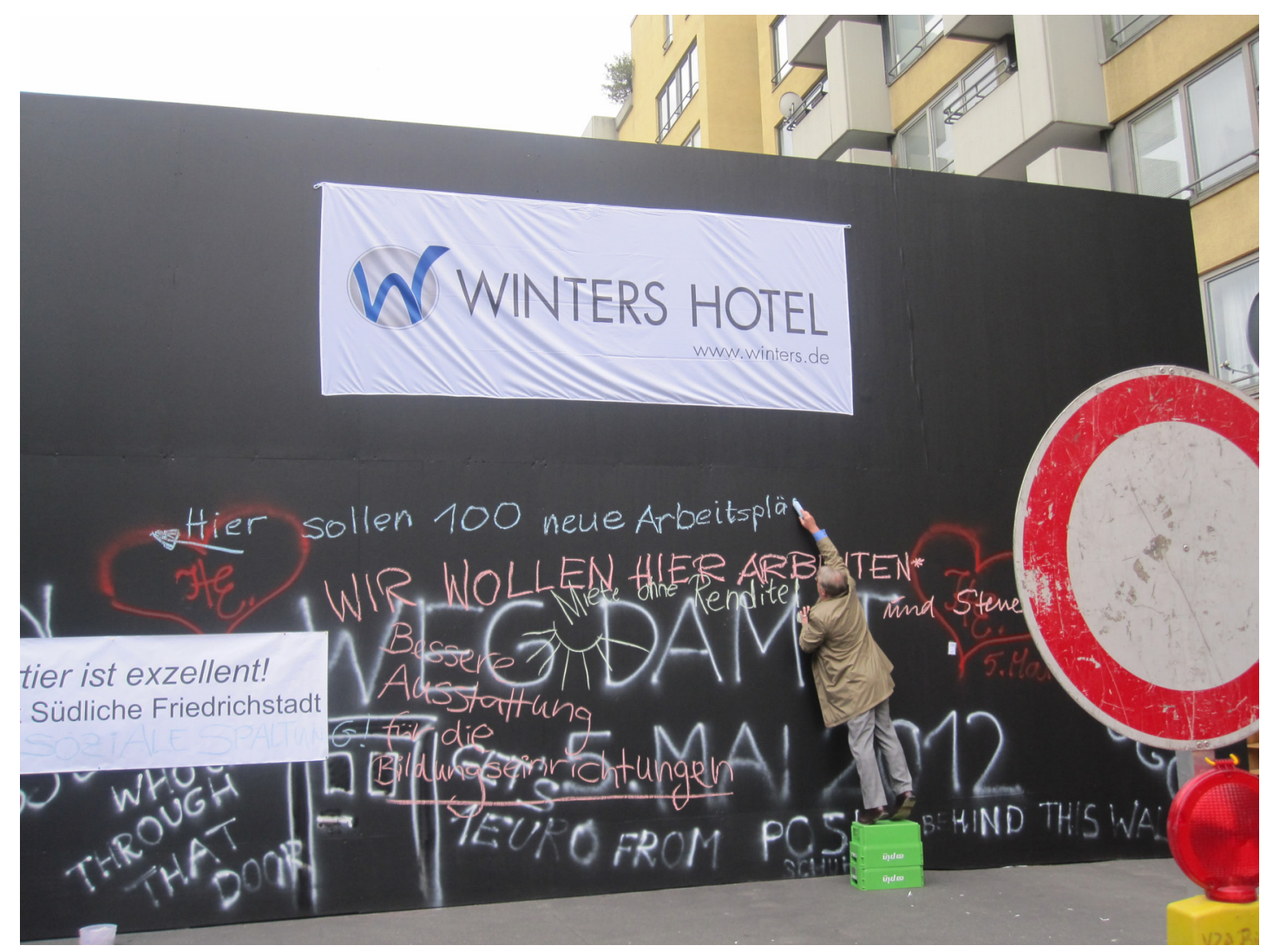

Peace Wall. Fot. Artur Żmijewski.

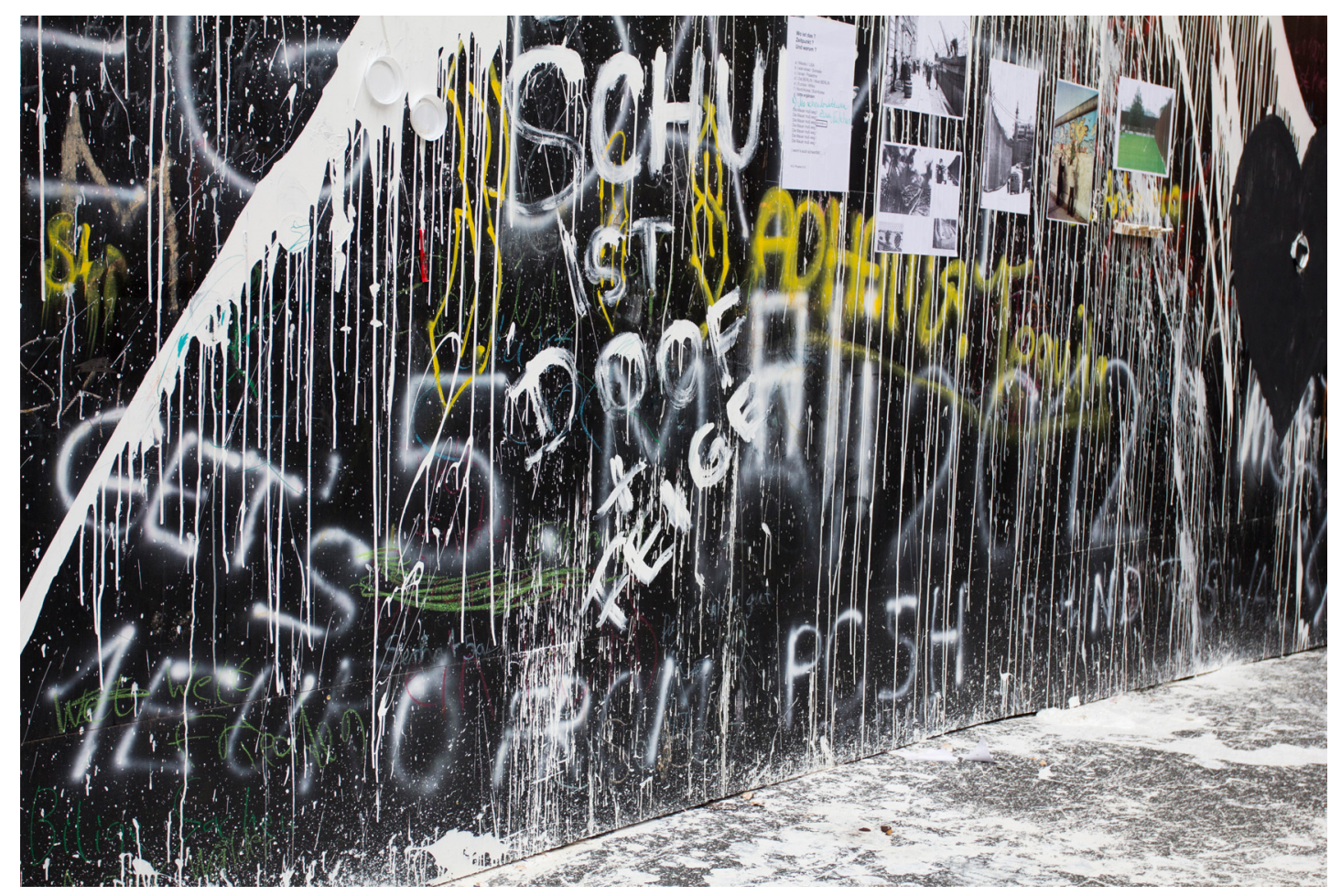

Peace Wall. Fot. Marta Górnicka. 


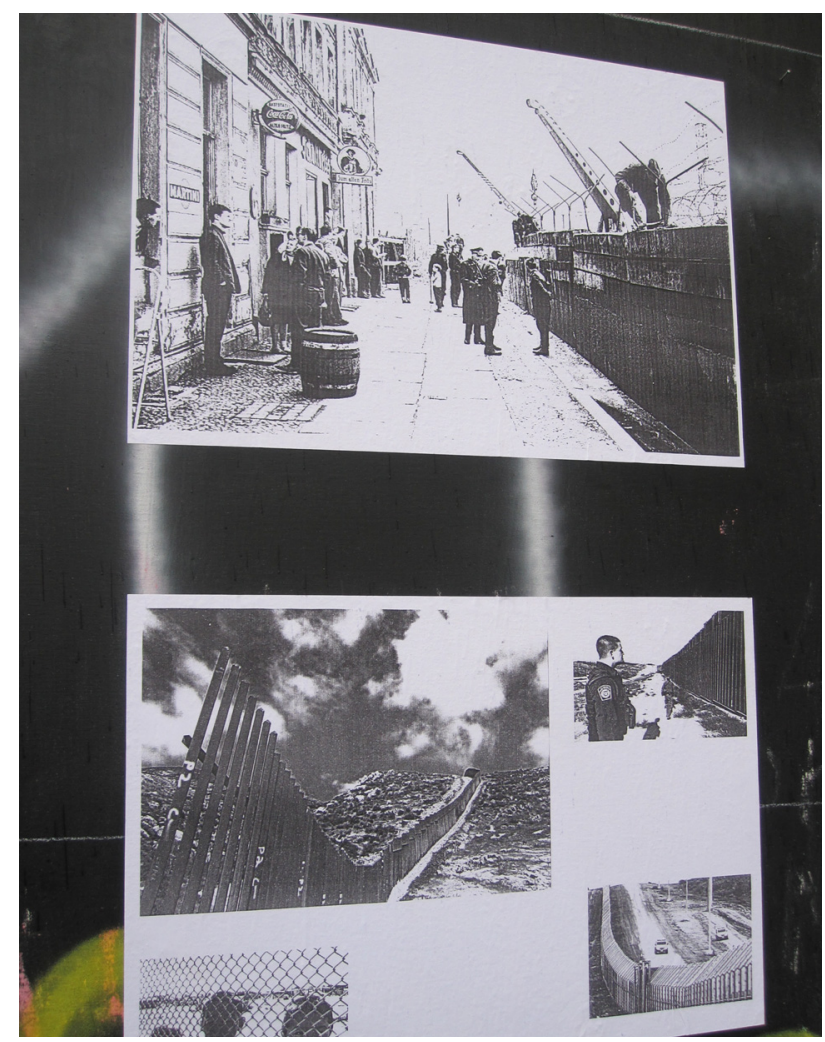

Peace Wall. Fot. Artur Żmijewski.

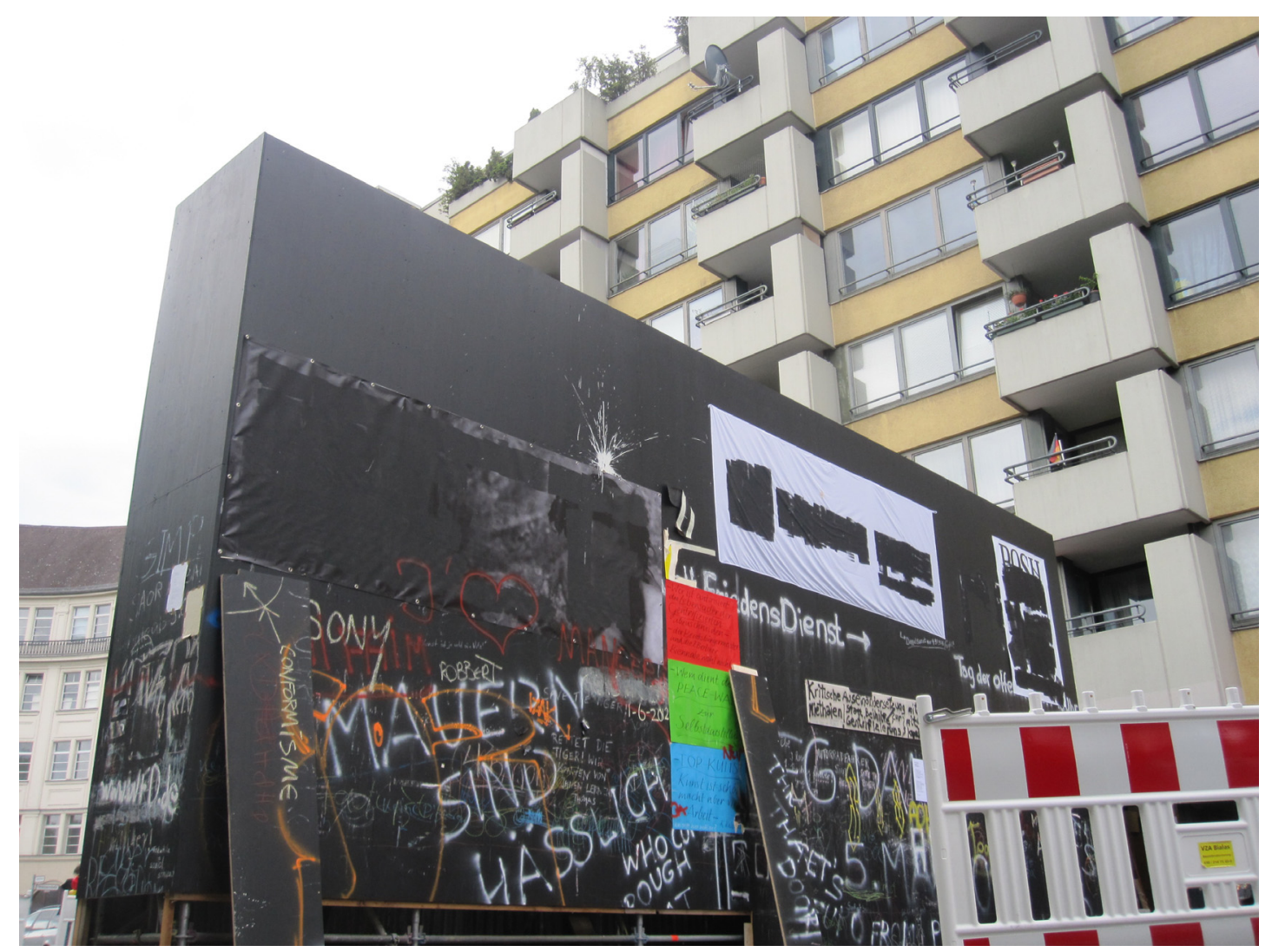

Peace Wall. Fot. Artur Żmijewski. 


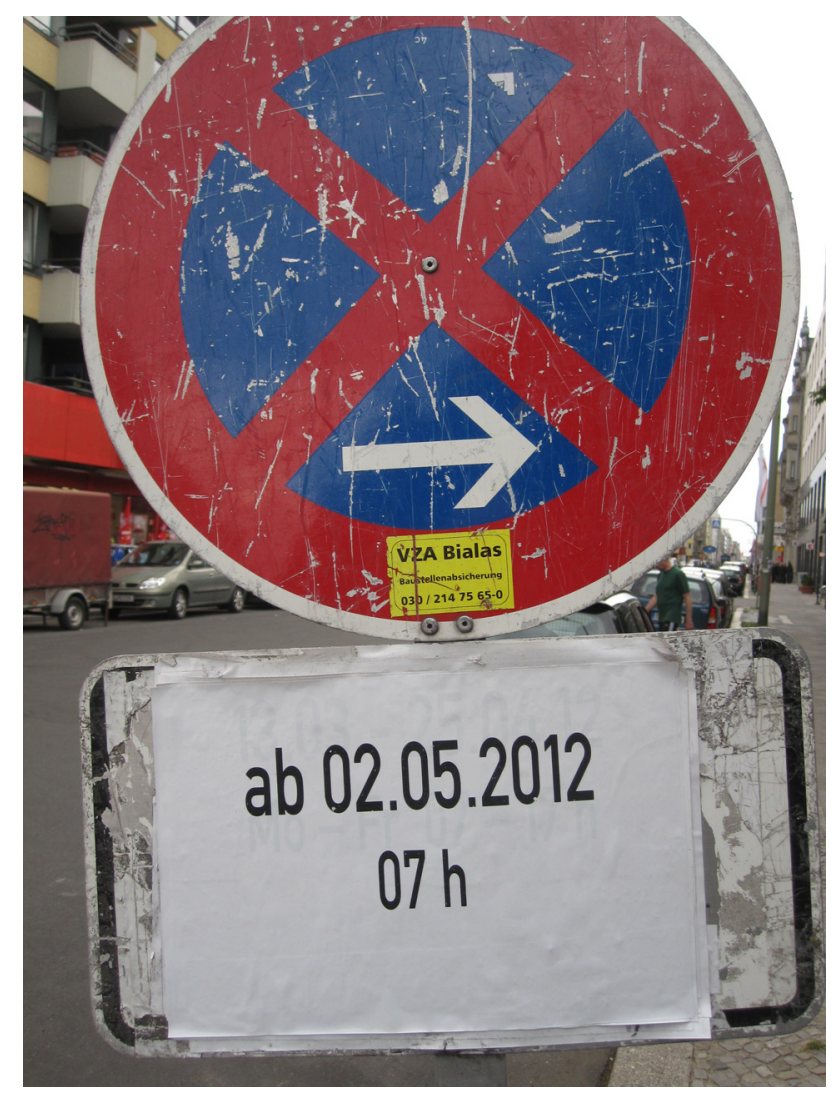

Peace Wall. Fot. Artur Żmijewski.

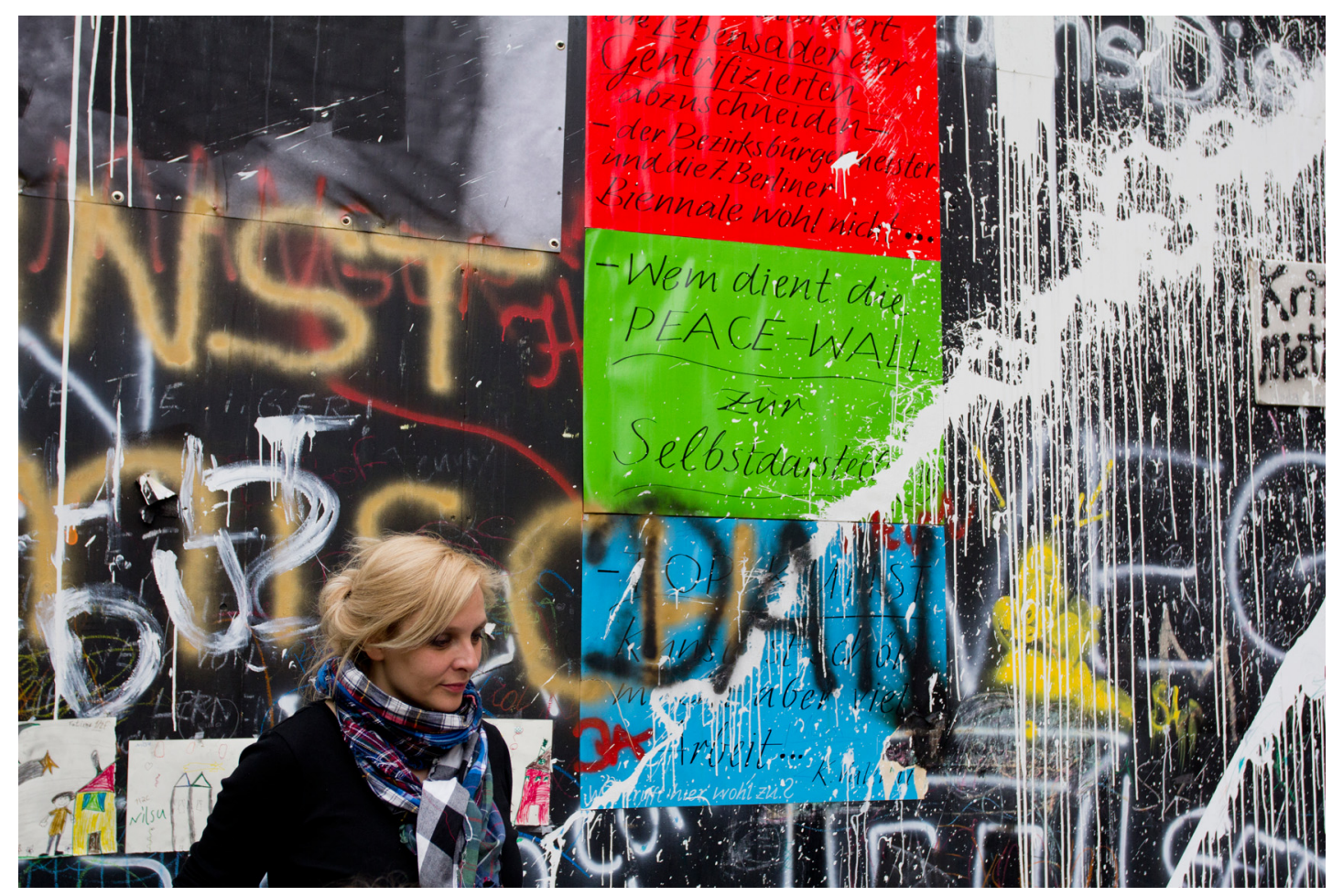

Nada Prlja. Fot. Marta Górnicka. 
- Hier sollen 100 neue Arbeitsplätze entst - ATE EOulgue

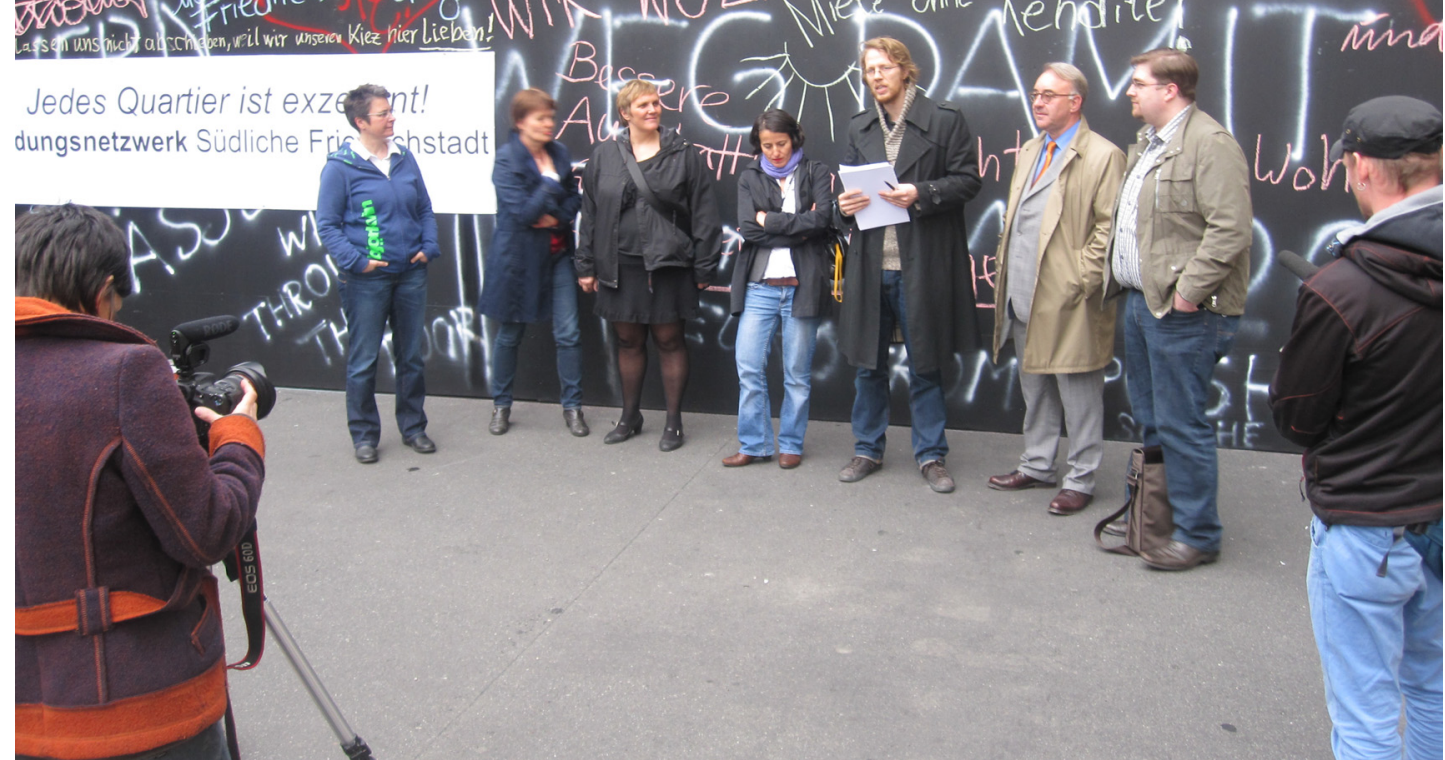

Peace Wall. Fot. Artur Żmijewski.

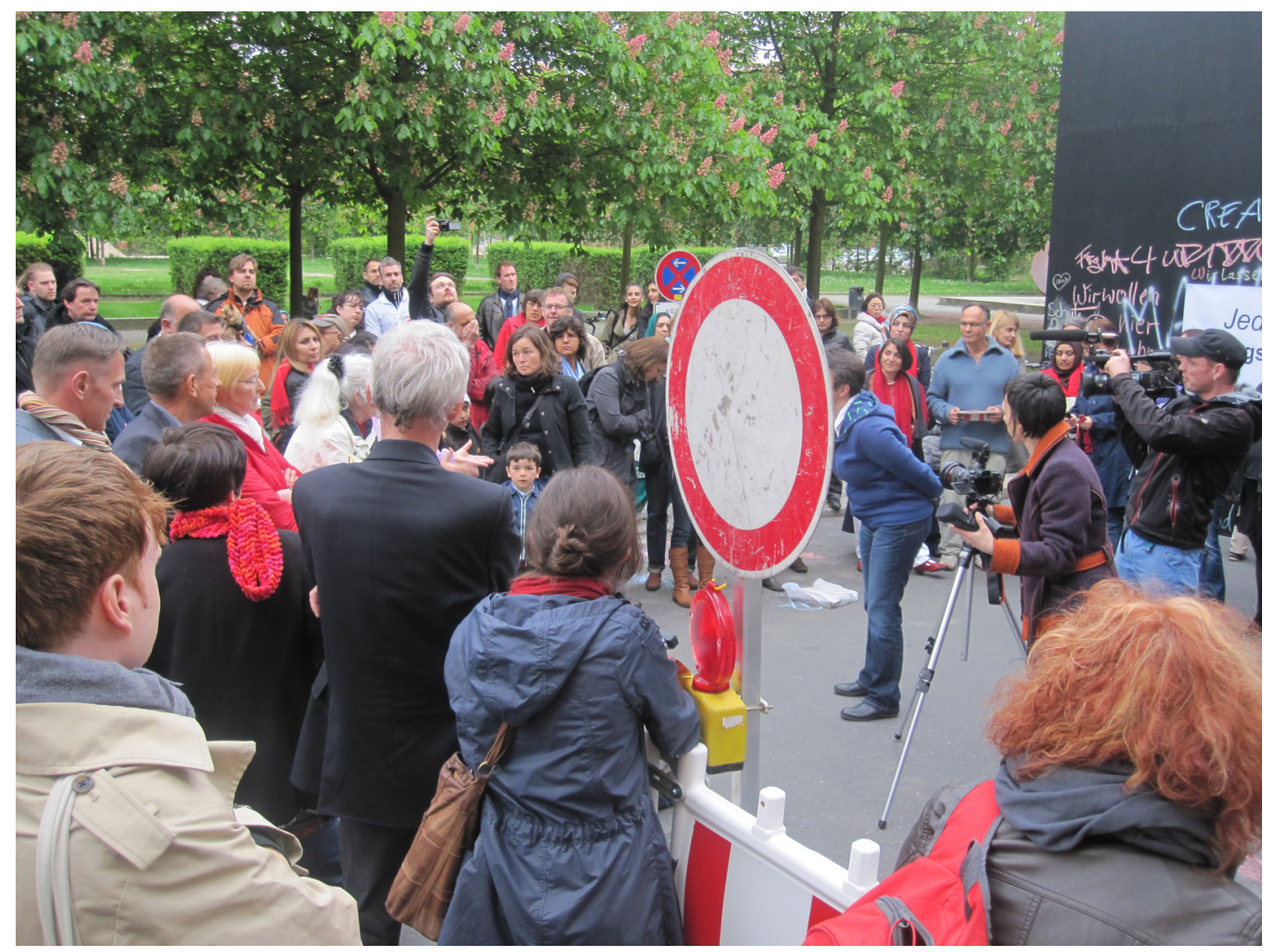

Peace Wall. Fot. Artur Żmijewski. 


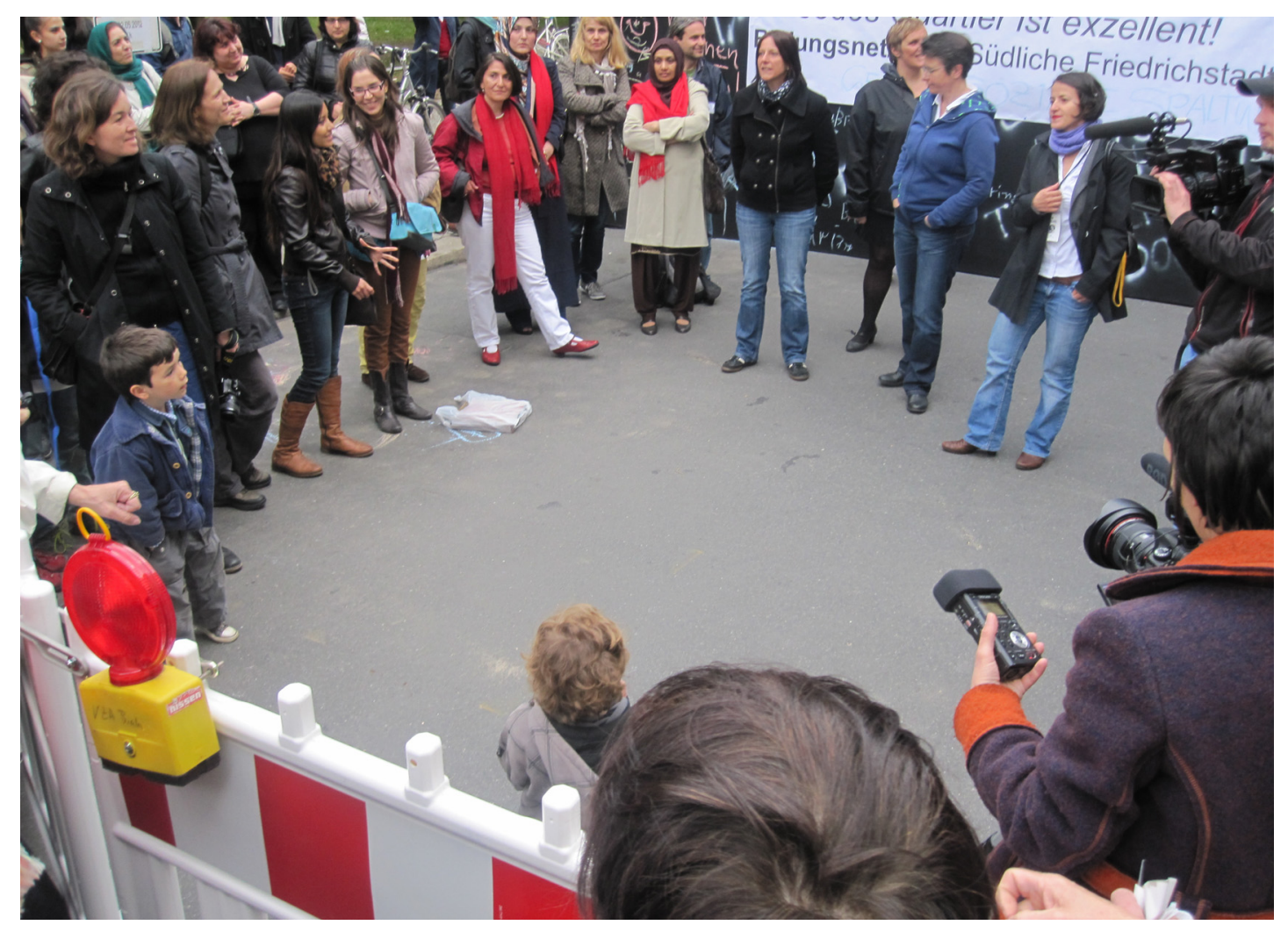

Peace Wall. Fot. Artur Żmijewski.

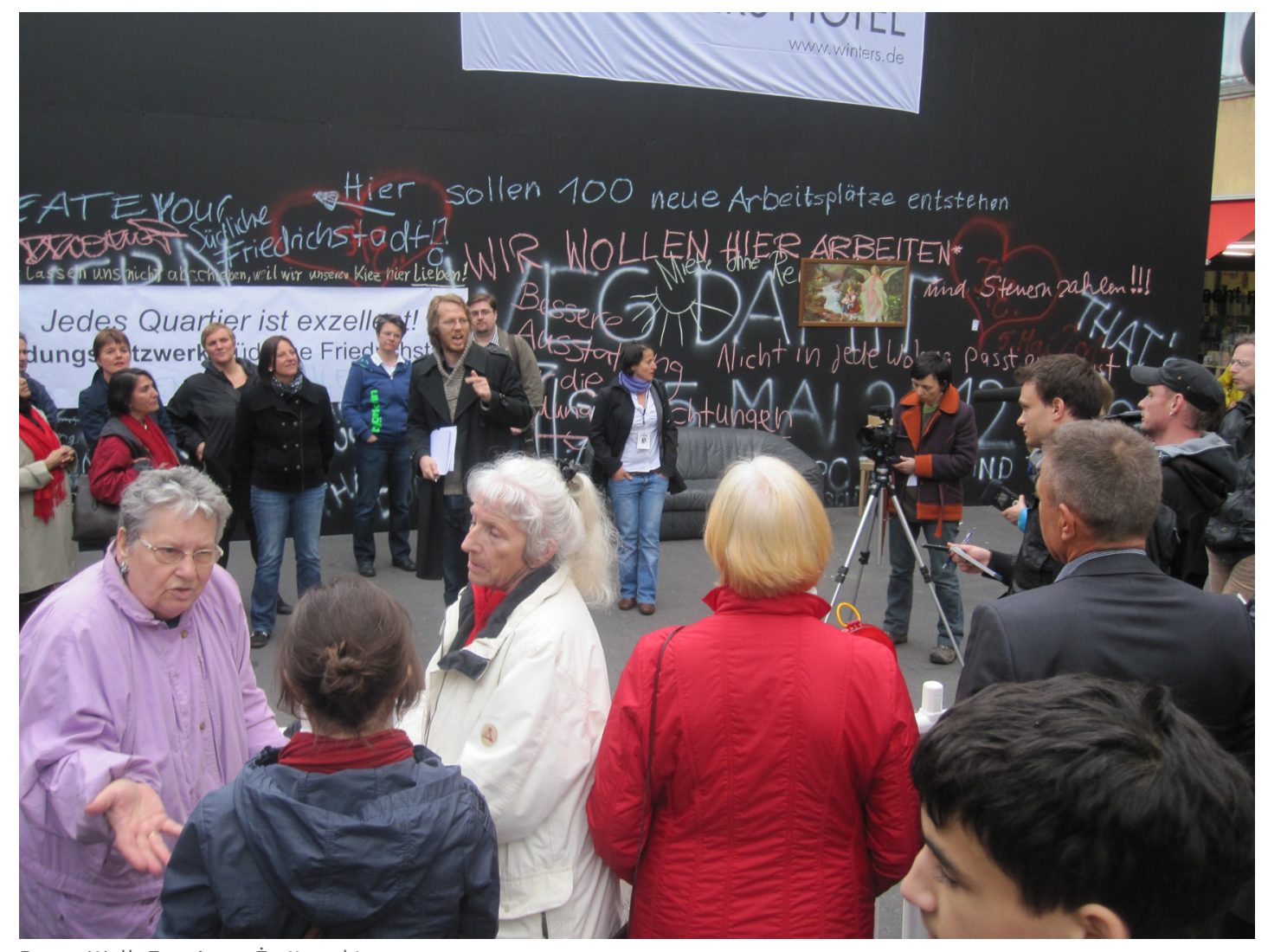

Peace Wall. Fot. Artur Żmijewski. 


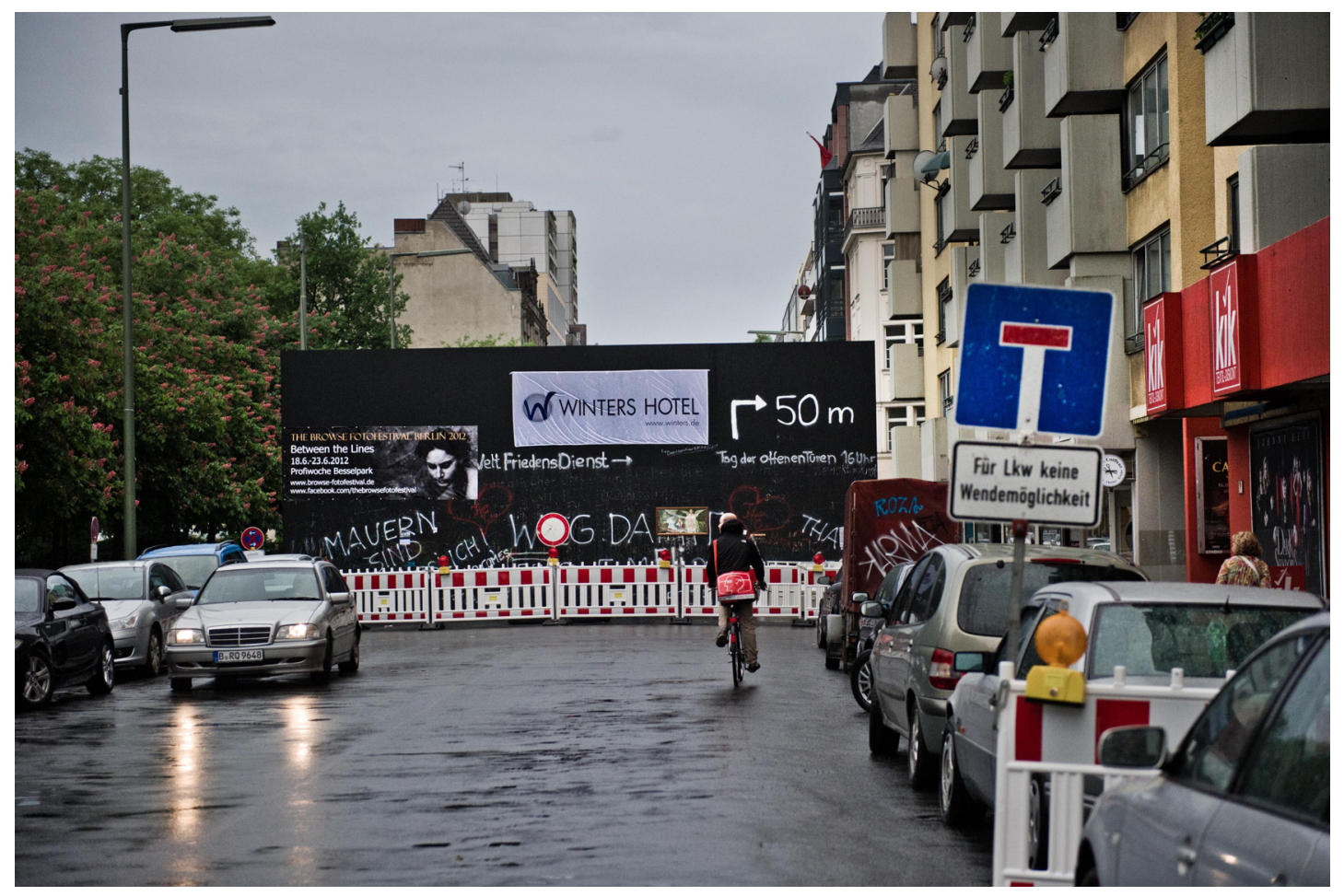

Peace Wall. Fot. Marcin Kaliński. @ Copyright by Marcin Kaliński

\section{An interview with Nada Prlja}

Abstract: Nada Prlja is an artist who works in the public space and tackles the issues of social inequalities and exclusion. During the 7th Berlin Biennale for Contemporary Art, she built a Peace Wall across Friedrichstrasse and thus she blocked the passage between the northern part of the street, which is a tourist attraction, and where expensive shops and restaurants are located; and its southern part, which is inhabited mainly by immigrants, who live in council flats. Nada Prjla tried to visualise the symbolic divide between the rich and the poor part of the street by putting the wall up, whose name alludes to the peace walls that split Protestants and Catholics in Northern Ireland.

Keywords: peace wall, gentrification, social inequalities, immigrants, urban policies, socially engaged art 